Published in final edited form as:

Antiviral Res. 2009 October ; 84(1): 1-13. doi:10.1016/j.antiviral.2009.06.006.

\title{
Vaccinia Virus Vaccines: Past, Present and Future
}

\author{
Bertram L. Jacobs ${ }^{a, b},{ }^{*}$, Jeffrey O. Langland ${ }^{a, c}$, Karen V. Kiblera $^{\mathrm{a}}$, Karen L. Denzlera $^{\mathrm{a}}$, Stacy D. \\ White $^{\mathrm{a}}$, Susan A. Holechek ${ }^{\mathrm{a}}$, Shukmei Wong ${ }^{\mathrm{a}}$, Trung Huynh ${ }^{\mathrm{a}}$, and Carole R. Baskina,d,e \\ a School of Life Sciences, Arizona State University, Tempe, Arizona \\ b Center for Infectious Diseases and Vaccinology, The Biodesign Institute, Arizona State University, \\ Tempe, Arizona \\ c Southwest College of Naturopathic Medicine, Tempe, Arizona \\ d Department of Comparative Medicine, University of Washington, Seattle, Washington \\ e Washington National Primate Research Center, University of Washington, Seattle, Washington
}

\section{Abstract}

Vaccinia virus (VACV) has been used more extensively for human immunization than any other vaccine. For almost two centuries, VACV was employed to provide cross-protection against variola virus, the causative agent of smallpox, until the disease was eradicated in the late 1970s. Since that time, continued research on VACV has produced a number of modified vaccines with improved safety profiles. Attenuation has been achieved through several strategies, including sequential passage in an alternative host, deletion of specific genes or genetic engineering of viral genes encoding immunomodulatory proteins. Some highly attenuated third- and fourth-generation VACV vaccines are now being considered for stockpiling against a possible re-introduction of smallpox through bioterrorism. Researchers have also taken advantage of the ability of the VACV genome to accommodate additional genetic material to produce novel vaccines against a wide variety of infectious agents, including a recombinant VACV encoding the rabies virus glycoprotein that is administered orally to wild animals. This review provides an in-depth examination of these successive generations of VACV vaccines, focusing on how the understanding of poxviral replication and viral gene function permits the deliberate modification of VACV immunogenicity and virulence.

\section{Keywords}

poxvirus; orthopoxvirus; smallpox; biodefense; vaccinia virus; vaccine vector; vaccination complications; vaccinia E3L

\section{Introduction}

Vaccination against smallpox, first introduced by Edward Jenner more than 200 years ago, was the single most effective public health intervention in human history. From its origin on a farm in Gloucestershire, England, vaccination spread around the world, leading eventually to a global campaign that eradicated smallpox in the late 1970s. Although the elimination of the

*Corresponding Author: Bertram L. Jacobs, School of Life Sciences, CIDV/Biodesign, Arizona State University, Box 875401, Tempe, AZ 85287-5401, Phone 480 965-4684, FAX 480 727-7615, bjacobs@ asu.edu.

Publisher's Disclaimer: This is a PDF file of an unedited manuscript that has been accepted for publication. As a service to our customers we are providing this early version of the manuscript. The manuscript will undergo copyediting, typesetting, and review of the resulting proof before it is published in its final citable form. Please note that during the production process errors may be discovered which could affect the content, and all legal disclaimers that apply to the journal pertain. 
disease was followed by the termination of national vaccination programs, interest in VACV, the smallpox vaccine, did not end. Over the past three decades, a number of novel attenuated variants of VACV with improved safety profiles have been produced through a variety of laboratory methods. At the same time, the ability of the VACV genome to accommodate additional genetic material has enabled molecular virologists to produce a large number of candidate vaccines that target a wide range of microbial pathogens.

In this article we review how VACV has been developed over the past four decades as a candidate vaccine for a variety of uses, and discuss how genetic engineering could lead in the future to new VACV vaccines that are both safe and highly immunogenic. We first discuss the replication and immunogenicity of the wild-type (wt) VACV employed during the smallpox vaccination campaign ("first-generation" $\mathrm{VACV}$ ) and newer forms of wt (second-generation) VACV that are now being stockpiled for defense against a possible re-introduction of smallpox by terrorists. We then review forms of third-generation VACV that were attenuated through sequential passage in an alternative host and fourth-generation viruses produced through "engineering" of the VACV genome. We then examine the potential need for rapidly immunogenic forms of VACV that could be used for postexposure vaccination in the event of a re-introduction of smallpox through bioterrorism. In the final section, we review how VACV is being used as a vehicle to develop novel vaccines against heterologous agents, and discuss how future efforts should focus on both safety and immunogenicity.

\section{Orthopoxvirus antigenic cross-reactivity and replication strategy}

The family Poxviridae is divided into 8 genera. Of greatest interest to humans is the genus Orthopoxvirus, which includes variola virus, the agent of smallpox, cowpox virus, the original vaccine used by Jenner, and VACV, which apparently replaced cowpox virus for use in vaccination some time in the $19^{\text {th }}$ century. Because of the highly conserved nature of orthopoxvirus structural proteins, immunization with VACV provides cross-protection against variola and other orthopoxviruses, such as monkeypox.

Poxviruses have large genomes (130,000-375,000 nucleotides), allowing the insertion and high level expression of large foreign genes, making them ideal as recombinant vaccine vectors. Several features of the poxvirus replication cycle also influence how these agents are employed as vaccines. Soon after the virion core enters a cell, early gene transcription results in the production of a wide variety of immunomodulatory proteins that block innate antiviral defenses, including the type I interferon (IFN) response. As discussed below, deletion or modification of these viral genes has proved to be an effective method of modifying VACV virulence. Later in the replication cycle, infectious virus is produced first in the form of intracellular mature virions (MV), which form the basis of all VACV vaccines. Further maturation is required to produce the extracellular enveloped virions $(\mathrm{EV})$ that are required for the extracellular spread of VACV. Deletion of genes encoding EV proteins such as B5R has also resulted in attenuated VACV vaccines (see below).

\section{Vaccine development before the global smallpox eradication campaign}

Historically, the first efforts at immunization against smallpox were practiced as early as 1000 CE involving a process known as variolation (Radetsky, 1999). This involved deliberate inoculation either by insufflation or scarification (Fenner, 1988) of an individual using variola virus obtained from the smallpox pustules of a patient with active disease, which typically resulted in a severe localized reaction, a generalized rash, and constitutional symptoms, but with a case fatality rate of $0.5-2 \%$ compared to $20-30 \%$ following natural variola infection. Despite the high incidence of complications, variolation was commonly practiced up until the beginning of the $19^{\text {th }}$ century. 
Because all orthopox viruses are antigenically related, immunization with nearly any orthopoxvirus can protect against challenge with other orthopoxviruses (Figure 1). In the late 1700s, Edward Jenner discovered that cowpox virus could be used successfully to protect humans against smallpox. Since vaccination with cowpox was much safer than variolation, it quickly became the primary method of conferring protection. Over time, VACV replaced cowpox virus as the agent used for vaccination. Of note, VACV is genetically distinct from either cowpox virus or variola virus, and its origin remains unknown, although it is most closely related to horsepox virus (Tulman et al., 2006). Jennerian vaccine viruses represent the $1^{\text {st }}$ generation of orthopox virus vaccines as vectors (Table 1).

\section{First-generation VACV vaccines and global smallpox eradication}

Humans are the only known natural reservoir for variola virus. Due to this and the effectiveness of the VACV vaccine, an intensified global smallpox eradication program was begun in 1966 (Parrino and Graham, 2006; Rotz et al., 2001). The basic strategy for this program involved mass vaccination campaigns in each country and the development of surveillance systems to detect and contain outbreaks. Thanks to these measures, the last naturally occurring case of smallpox occurred in Somalia in 1977, and in May 1980, the World Health Assembly certified that the world was free of naturally occurring smallpox (Rotz et al., 2001; Wehrle, 1980). In 1982, the only active licensed producer of VACV vaccine in the United States discontinued production for general use, and in 1983, distribution to the civilian population was discontinued (Rotz et al., 2001).

During the smallpox eradication program, the majority of the vaccine was manufactured on the skin of live animals including calves, sheep, buffaloes and rabbits (2002). Many VACV strains were used during the eradication program. The New York City Board of Health $(\mathrm{NYCBH})$ strain was used in the Americas and in West Africa. Following the eradication program and continuing until August 2007, the Wyeth Laboratories, Inc. Dryvax ${ }^{\circledR}$ vaccine was the only commercially approved smallpox vaccine available for limited use in the United States (Rosenthal et al., 2001). The Dryvax ${ }^{\circledR}$ vaccine was manufactured from the lymph fluid of calves' skin infected with the NYCBH strain. The EM-63 strain used in Russia was a derivative of the NYCBH strain and was widely used in the eradication of smallpox in India (2002). The Lister or Lister/Elstree strain was developed at the Lister Institute in the United Kingdom. From 1968 to 1971, the Lister strain became the most widely used vaccine throughout the world (Rosenthal et al., 2001).

Additional vaccine strains included the Paris strain (France), the Copenhagen (Cop) strain (Denmark), the Bern strain (Switzerland), the Ankara strain (Turkey), the Temple of Heaven and the Vaccinia Tian Tan (VTT) strains (China), and the Dairen strain (Japan). A 2006 study suggested that adverse complications vary considerably among the different vaccine strains (Kretzschmar et al., 2006). Overall, vaccination with the NYCBH strain caused the lowest rate of adverse effects, whereas vaccination with the Lister strain led to an intermediate rate of adverse effects. The Copenhagen strain led to intermediate/high rates of adverse events and the Bern strain led to the highest rate of adverse reactions (Kretzschmar et al., 2006).

\section{B. Nature of the vaccine "take" and vaccination complications}

Typically following vaccination, a vesicular or pustular skin lesion at the site of inoculation is indicative of a successful vaccination or "take". With the current concern of variola virus being reintroduced into the human population through a bioterrorism event or of the emergence of monkeypox as a significant human pathogen, the use, efficacy and safety of the VACV vaccine is being re-evaluated (Kretzschmar et al., 2006; Neff et al., 2008; Parrino and Graham, 2006). Forty to $47 \%$ of vaccinees report mild pain at the site of inoculation and 2-3\% reports the pain as severe. Fever is common after vaccination with $5-9 \%$ reported above $100^{\circ} \mathrm{F}\left(37.7^{\circ} \mathrm{C}\right)$ and 
$3 \%$ above $102^{\circ} \mathrm{F}\left(38.8^{\circ} \mathrm{C}\right)$ (Kretzschmar et al., 2006; Rotz et al., 2001). In addition, many vaccinees report a variety of mild systemic complications, including headache, myalgia, chills, nausea and fatigue (Table 2). Moderate and severe complications of VACV vaccination include eczema vaccinatum (in vaccinees with a history of eczema or atopic dermatitis), generalized vaccinia, progressive vaccinia (in immunocompromised vaccinees), myopericarditis and postvaccinial encephalitis (mostly in children) (Table 1). Moderate to severe complications occur in approximately 1 to 250 individuals per million primary vaccines (Rotz et al., 2001). Because of the recently identified high incidence of myopericarditis, increased surveillance for cardiac events during clinical trials for future smallpox vaccines will be imperitive (Sniadack et al., 2008).

\section{Replication and immunogenicity of wild-type vaccinia viruses}

The ability of live VACV vaccines to replicate and generate a protective immune response following challenge has been well documented. The replication capacity of these vaccines in tissue culture cells has shown a broad host range as well as ability to replicate in multiple cell types. In laboratory settings, these viruses are routinely grown in kidney-derived cell lines made from non-human primates such as Vero and BSC-1/BSC-40 cells (Abdalrhman et al., 2006; Meseda et al., 2005; Zhu et al., 2007), from rabbit such as RK-13 (Kidokoro et al., 2005), or hamster (BHK-21) (Jentarra et al., 2008; Vijaysri et al., 2008) sources. Kidneyderived fibroblast cell lines such as BHK-21 seem to be especially permissive for replication and therefore are widely used for preparation of viral stocks. This may be due to the presence of an inhibitor of the interferon-induced PKR protein that has been partially characterized in these cells in our lab (Langland and Jacobs, unpublished observations). Epithelial and fibroblast cell lines from human cervix or lung tissues (HeLa, MRC-5, A549) (Legrand et al., 2004; Sharon et al., 2007; Verardi et al., 2001; Wyatt et al., 2004) and murine fibroblastic cell lines (L929, NIH3T3) (Verardi et al., 2001; Zhu et al., 2007) are also used to grow viral stocks as well as test viral replicative capacity and host range.

The ability of a particular VACV strain to grow in certain cell lines does not always correlate linearly with local or systemic virulence in vivo (Abdalrhman et al., 2006; Fang et al., 2005; Verardi et al., 2001). Therefore, the replication capacity of VACVs has to be further characterized by measuring viral load in tissues after vaccination or infection. The highly neuropathogenic Western Reserve (WR) strain, originated from passaging the NYCBH strain in mice, replicates to high titers in nose, lungs, brain, ovaries, and skin of that species; (Brandt et al., 2005; Jentarra et al., 2008; Vijaysri et al., 2008). The Wyeth and Lister strains also replicate well in lungs of mice, but replicate at least three orders of magnitude lower in the brain than WR following intranasal (IN) infection (Abdalrhman et al., 2006; Hayasaka et al., 2007). NYCBH grows nearly as well as WR in skin of mice, while Wyeth strain isolates (Dryvax ${ }^{\circledR}$ ) grow to 6- to 20-fold lower titers than WR (Lee et al., 1992).

Concurrent with replication on the skin is the formation of pocks that signify a positive vaccine "take". A dose of $1 \times 10^{5}$ plaque-forming units (pfu) WR is required for $100 \%$ pock formation in mice, while VACV Lister requires only $2 \times 10^{3}$ pfu (Jentarra et al., 2008; Sharon et al., 2007). The discrepancy between these two strains could be due to the fact that WR is a neuroadapted strain and may not replicate as well on skin when administered at lower doses. Despite the higher take efficiency of the Lister strain, a $1 \log$ higher dose is required to fully protect mice upon wild type lethal challenge (Sharon et al., 2007). In contrast, a dose of $2 \times$ $10^{4} \mathrm{pfu}$ of the NYCBH or Cop strain gives mild pock formation but is sufficient to protect mice from lethal wild type challenge (Table 4).

In summary, a "take" may indicate a certain level of localized or systemic viral replication, but may not necessarily be enough to completely protect an animal from lethal challenge. Traditionally, a dose of $2.5 \times 10^{5} \mathrm{pfu}$ of a replicating wt VACV strain is given to induce 
protection in humans although it should be noted that dilutions of Dryvax® appear to provide protective immunity (Couch et al., 2007; Miller et al., 2008). Historically, protection against smallpox in humans has been found to be due to the presence of neutralizing antibodies in the sera of infected individuals (Downie and McCarthy, 1958; Mack et al., 1972). In experiments using mice vaccinated and challenged with wt VACVs, neutralizing antibodies are measurable after vaccination with VACV Lister at the 2 highest doses $\left(5 \times 10^{4}\right.$ to $5 \times 10^{5} \mathrm{pfu}$ ) (Abdalrhman et al., 2006), and at the higher dose, neutralizing antibody levels steadily increase during the year following vaccination (Ferrier-Rembert et al., 2008). However, the induction of protection does not always correlate with levels of neutralizing antibodies induced upon vaccination. Scarification with $1 \times 10^{6} \mathrm{pfu}$ VACV WR induces high levels of neutralizing antibodies, while scarification with the same dose of either the weaker VACV NYCBH or the VACV Cop strain does not induce high levels of neutralizing antibodies but nevertheless provides protection against lethal challenge (Jentarra et al., 2008) and unpublished observations).

Immunization with wt VACVs induces activation of CD8+ lymphocytes that serve as additional correlates of protection. In humans, immunization with $2.5 \times 10^{5}$ pfu Dryvax ${ }^{\circledR}$ induces an effector CD8+ cell population in which 3-14\% of CD8+ T cells produce IFN- $\gamma$ upon ex vivo stimulation. At 1 month post-vaccination, these CD8+ cells display memory cell markers and at 6 months post-vaccination, these cells can be reactivated (Miller et al., 2008). In mice, scarification with Dryvax ${ }^{\circledR}$ and VACV Lister induce IFN- $\gamma$-secreting CD8+ cells which are measurable for 5 months post-vaccination (Ferrier-Rembert et al., 2008). The specific involvement of CD8+ cells was tested by antibody depletion studies in naive mice followed by challenge. $\mathrm{CD} 8+$ cells were required for prevention of weight loss in naïve animals, presumably by providing a non-specific cell-mediated response until the advent of a humoral response (Belyakov et al., 2003). Further support for the importance of an early and nonspecific cell-mediated response is seen in immunization of B-cell-deficient mice. Upon challenge, these animals display an initial weight loss but recover completely (Belyakov et al., 2003).

\section{Second-generation vaccines: new forms of wild-type VACV}

The use of live animals for the production of vaccine material has changed due to current unacceptability of this process and quality control issues regarding microbial contamination. This has led to the production of "second generation" smallpox vaccines using tissue culture systems or embryonated chicken eggs. VACV vaccine prepared in embryonated chicken eggs was used in large scale during the eradication campaign in South America and is the standard commercial vaccine in Israel. However, experience with vaccine material produced in cell culture is limited. Vaccine was prepared on chick embryo fibroblasts in Japan before eradication of the disease, but its effectiveness is not well documented (Fenner, 1988).

ACAM $2000^{\mathrm{TM}}$ is a "second generation" smallpox vaccine licensed for use in the United States as of August 2007. The vaccine was derived from plaque purification of a Dryvax ${ }^{\circledR}$ isolate that was subsequently manufactured in the Vero monkey cell line. For the naïve population, the percentage of "takes" and complications using ACAM2000" vaccinees. ACAM $2000^{\mathrm{TM}}$ was also found to be acceptable as a booster in those previously vaccinated for smallpox. Nevertheless, a significant minority of the population has contraindications that prevent pre-exposure use of "first" or "second generation" smallpox vaccines (Greenberg and Kennedy, 2008). Therefore substantial work is being directed toward the development of safer, yet immunogenic vaccines. These "third generation" vaccines involve genetically altering the VACV genome in order to create non-replicating or highly attenuated VACV strains that still retain their immunizing properties against smallpox. 


\section{Third-generation vaccines: attenuation through sequential passage}

One commonly used technique to attenuate VACVs involves multiple passaging of the wt viruses in tissue culture cells from alternative hosts, which has been shown to alter properties such as viral host range, virulence, and genome composition. Passaging of viruses through alternative hosts has been used for over 80 years to obtain attenuated viral strains (Monath, 2005). Arguably the most effective human viral vaccine, the 17D yellow fever virus vaccine, was obtained by nearly 400 passages of the yellow fever virus through primary mouse and chicken cells in culture. In the case of VACV, there are three current vaccine candidates that have been obtained by passage through alternative hosts, Lister clone 16m8 (LC16m8), Modified Vaccinia Ankara (MVA) and Dairen I Strain (DIs).

\section{A. LC16m8}

LC16m8 was developed in Japan in 1975, by passaging the Lister strain through primary rabbit kidney epithelial cells (PRK) at a low temperature $\left(30^{\circ} \mathrm{C}\right)$ (Kenner et al., 2006). The Lister virus was initially passaged 36 times through PRK cells, and individual clones were then evaluated for growth on monkey kidney Vero cells, in order to gauge their ability to replicate in primate tissues. LC16, which grew to the lowest titer in Vero cells, was passaged 6 more times under identical conditions. LC16m0, which formed medium-sized pocks on chick chorioallantoic membranes (CAM), was isolated from this stock and passaged 3 more times on PRK cells. LC16m8 was then isolated from this latter stock as a clone that both replicated poorly in Vero cells and formed small plaques on CAM, PRK, and RK13 cells. In vivo, LC16, LC16m0 and LC16m8 strains have a take rate similar to the Lister strain, but are temperaturerestricted, have limited host range and greatly reduced adverse effects, including neurovirulence (Kenner et al., 2006).

The in vitro phenotype of the $\mathrm{LC} 16 \mathrm{~m} 8$ clone was attributed to a frame-shifting single nucleotide deletion in the B5R gene, in contrast to the Lister and LC16m0 viruses (Morikawa et al., 2005; Takahashi-Nishimaki et al., 1991). The B5R gene encodes an EV protein, with homology to complement regulatory proteins (Takahashi-Nishimaki et al., 1991) which is essential for efficient EV formation. EVs are necessary for effective virus dissemination, both in cells in culture and within an infected host (Herrera et al., 1998). Presumably the lack of EV formation in cells infected with LC16m8 leads to the small plaque phenotype in RK cells, and the failure to form plaques in Vero cells. Since this phenotype is caused by a single base pair deletion, the LC16m8 strain can easily revert to the wild type version, and the small plaque phenotype in particular is unstable on passage (Kidokoro et al., 2005). A stabilized version of LC16m8, containing a deletion of the entire B5R gene, has been developed to overcome this problem (Kidokoro et al., 2005). The mutation(s) responsible for the temperature restriction and in vivo attenuation phenotypes of LC16, LC16 0 and $\mathrm{LC} 16 \mathrm{~m} 8$ may be likewise unstable. While the relevant loci have not yet been mapped, there are no large deletions in the genome of LC16m8, compared to non-attenuated strains, and 192 of the 198 major Open Reading Frames (ORFs) of VACV Cop are open in LC16m8 (Morikawa et al., 2005).

VACVs containing mutations in B5R, as that found in LC16m8, may have unique utility in people with pre-existing immunity to VACV. Since B5R is the primary target of neutralizing antibodies in response to EV (Bell et al., 2004), Viner et al. theorized that deletion of the B5R gene would be a means to overcome pre-existing immunity to VACV among those who have received smallpox vaccinations. Further, they also reported that the deletion of B5R in conjunction with use of the thymidine kinase (TK) locus for expression of a heterologous protein resulted in a vector with reduced virulence (Viner et al., 2007). However, the lack of induction of immunity to B5R may make $\mathrm{LC} 16 \mathrm{~m} 8$ a less efficient vaccine for protection against orthopoxviruses. 


\section{B. Modified Vaccinia Ankara}

MVA was derived in the late 1950s by passaging the chorioallantois VACV Ankara (CVA) strain of VACV more than 570 times in chick embryo fibroblast (CEF) cells, resulting in a host range restricted virus that is replication-defective in most mammalian cells (McCurdy et al., 2004). This highly attenuated strain is unable to replicate in human cells and in clinical trials presented no adverse reactions (Sutter and Moss, 1995). MVA was safely used to vaccinate over 100,000 people in Germany (Mayr, 2003), yet its effectiveness against smallpox remains untested.

An intermediate virus, CVA382, which is attenuated in mice, was obtained at the 382nd passage in CEF cells (Meyer et al., 1991). CVA382 has four large deletions, two each in the left and right species-specific terminal regions of the VACV genome, compared to CVA (Meyer et al., 1991). These regions of the genome contain non-essential genes that are often involved in evasion of the host innate immune response, and genes necessary for maintaining the broad host range of VACV. MVA has several additional large deletions in the terminal arms, and contains numerous point mutations relative to fully replication-competent VACV strains (Antoine et al., 1998; Meyer et al., 1991). In all, MVA appears to have lost nearly $30 \mathrm{~kb}$ of genomic information. Consequently, MVA replicates efficiently only in CEF and BHK cells. Replication is restricted in all human cells that have been tested (Meyer et al., 1991; Wyatt et al., 1998) and the virus is highly attenuated in mice (Meyer et al., 1991). In most cells MVA makes early, intermediate, and late proteins, but only immature virions are formed (Sutter and Moss, 1992). This is unique, in that most other host range restricted VACVs that have been identified lead to a block in viral protein synthesis (Meng et al., 2008), as opposed to a block in viral maturation.

Both CVA 382 and MVA contain a deletion in the K1L host range gene, a gene that is essential for replication in RK13 (Perkus et al., 1990) and other cells. While restoration of the missing sequences in the K1L gene restores replication of both viruses in RK13 cells, and partially restores replication in human Hep- 2 and Vero cells, it does not restore replication of MVA in human HeLa, MRC-5 and HRT-18 cells, nor does it restore pathogenicity in mice (Meyer et al., 1991; Wyatt et al., 1998). Thus, MVA contains additional host range-restricting mutations in addition to the deletion of K1L. These additional mutations all appear to affect nonoverlapping reading frames in the left terminal region of the genome, and restoration of this region in its entirety leads to a near normal host range (Wyatt et al., 1998).

MVA has been extensively studied as the "gold standard" for VACV-based vaccines. It is considered effective because it provides a complete antigenic dose by completing the already initiated replication cycle, an important characteristic for the generation of antibodies against late viral envelope proteins that are required for neutralization of VACVs, yet safe because it does not go through further cycles in primary human cells (Blanchard et al., 1998; Ludwig et al., 2005). MVA shows a similar antibody profile as Dryvax $\AA$, and produces antibodies to both membrane and core proteins (Davies et al., 2008). MVA has been shown to induce a protective immune response against monkeypox virus in non-human primates (Earl et al., 2004; Earl et al., 2008). In addition to having deletions in host range genes that may limit MVA replication in human cells, MVA lacks a number of immunomodulatory genes encoding soluble receptors for type I and type II IFNs, tumor necrosis factor (TNF), and CC chemokines (Blanchard et al., 1998). Lack of these immunomodulators affects the viral replication cycle by blocking host protein synthesis more effectively and by inducing apoptosis more rapidly which may augment antigen presentation and immunogenicity of MVA (Chahroudi et al., 2006; Larsson et al., 2001). However, a comparison study of VACV-based smallpox vaccines suggests that higher doses or multiple doses of MVA are required to achieve the immune protection seen with a single dose of wt replicating VACV. In the mouse model, MVA used at a 1-2 log higher dose than Dryvax ${ }^{\circledR}$ or in a prime-boost regimen is required to get VACV-specific CD8+ cells and 
IgGs to levels comparable to that of a single administration of the commercial vaccine (Meseda et al., 2005; Wyatt et al., 2004). Similarly, another study evaluated two doses of MVA (IMVAMUNE®) given prior to Dryvax® in an attempt to reduce adverse effects from Dryvax ${ }^{\circledR}$. This regimen indeed resulted in lessened localized reactions, but no higher neutralizing antibody titers and similar numbers of IFN- $\gamma$ producing cells were measured as compared to Dryvax ${ }^{\circledR}$ alone (Frey et al., 2007) (Kennedy and Greenberg, 2009).

\section{Dairen I Strain}

The DI strain of VACV was obtained after 13 serial passages of the parental Dairen (DIE) vaccine strain in 1 day old eggs (Tagaya et al., 1961). The DI strain was first noticed as forming tiny plaques on CAM, in contrast to the parental strain, and was isolated after several rounds of pock formation on CAM. DIs contains a $15.4 \mathrm{~kb}$ deletion in the left terminal region of the VACV genome, from C9 to K5L, that apparently occurred by homologous recombination between two 16 base pair sequences that are nearly identical (Ishii et al., 2002). This deletion encompasses the well-characterized host range genes, K1L and C7L, as well as the IFN resistance gene, K3L. Consequently, DIs has a highly restricted host range, which is not simply restored with replacement of $\mathrm{K} 1 \mathrm{~L}$ and $\mathrm{C} 7 \mathrm{~L}$, suggesting the existence of additional and yet unknown host-range genes in this region (Ishii et al., 2002). Of note, this deletion in the hostrange determining region of $\mathrm{VACV}$ is similar to, although more extensive than, the region deleted in the left arm of the genetically engineered third generation smallpox vaccine NYVAC (Paoletti et al., 1994).

\section{Comparison of $3^{\text {rd }}$-generation vaccines}

LC16m8, DIs and MVA have all been obtained by passage on alternative hosts. Nonetheless, while there are some similarities among the three viruses, there are numerous differences as well. DIs and MVA were both obtained by passage in chicken cells, and both have large deletions in the host range determining region, which makes both viruses replication defective in most mammalian cells. Despite this similarity in host range, MVA contains a functional C7L host range gene, while this gene is deleted in DIs. MVA was passaged more extensively than DIs, which may be responsible for the additional large deletions, and numerous small insertions and deletions present in MVA, in both the left and right terminal arms of the virus. These additional mutations in innate immune evasion genes in MVA may be responsible for the unique ability of this virus, among non-genetically engineered orthopoxviruses, to induce proinflammatory signal transduction, proinflammatory gene expression, and to lead to an increased migration of immune cells to the site of immunization (Guerra et al., 2007) (Lehmann et al., 2009). The ability of MVA to induce proinflammatory cytokines may have a profound influence on its ability to induce adaptive immunity. Induction of proinflammatory signaling and proinflammatory gene expression by DIs has not been reported. LC16m8 was obtained by passage through rabbit kidney cells, and rather than having large deletions it has one single base pair deletion in B5R, and likely has other small mutations that alter gene function to give the temperature restriction and low pathogenicity of this virus. LC16m8 has an intact host range determining region, and appears to be replication competent in most mammalian cells. Thus, the properties of these viruses as vaccines may be very different. As a replication competent virus LC16m8 may have properties closer to a wt-VACV than DIs or MVA. However, the failure to make EV may at least potentially affect the efficacy of $\mathrm{LC} 16 \mathrm{~m} 8$ as a replacement smallpox vaccine.

\section{Fourth-generation vaccines: attenuation through genetic engineering}

With the advances in biotechnology that allow insertion, deletion and interruption of genes in specific genomic sites, targeted attenuation of viruses became a practical goal. For VACV this has involved deletion of immune-modulating, host-range and accessory nucleotide metabolism 
genes, as well as deletion of essential genes, that can be complemented by cell lines expressing the targeted VACV gene. The goal of deleting genes from VACV is to attenuate the virus while maintaining or increasing immunogenicity. While attenuation can certainly be attained by deleting genes from VACV, there has been limited evidence that immunogenicity can be increased by deleting genes from VACV. Deletion of one of three genes, E3L, B15R/184R, or A41L can increase T-cell responses (Clark et al., 2006; Cottingham et al., 2008; Jentarra et al., 2008; Staib et al., 2005), but other single gene deletions, such as B8R, have had minimal effect (Alcami and Smith, 1995a; Alcami and Smith, 1995b). At best, immunogenicity appears to be maintained after deleting genes from VACV, although often only at higher doses compared to a more wt parent. This may be due to the need to delete gene families rather than single genes or to the limitations of historical analyses of immune responses. A summary of modifcations through genetic engineering is shown in Table 3.

\section{A. Attenuation through deletion of immune modulating, accessory, or essential genes}

One of the best characterized genetically attenuated mutants of VACV is NYVAC, which has a deletion of 18 open reading frames (ORFs) (Tartaglia et al., 1992). The deleted genes include a cassette of 12 ORFs spanning C7L through K1L, a host range region; TK; the hemorrhagic region, B13R and B14R; A26L, the A-type inclusion region; A56R, the hemagglutinin gene; and the ORF I4L, which encodes the large subunit of ribonucleotide reductase. NYVAC was derived from VAVC Cop, and is highly attenuated in human cell lines, but still retains the ability to induce strong immune responses (Paoletti et al., 1994; Tartaglia et al., 1994).

In non-permissive cells NYVAC progresses through early stages of viral replication and then stops (Najera et al., 2006). Consequently, a one log higher dose than MVA is required for seroconversion, probably due to lack of late stage protein expression (Ferrier-Rembert et al., 2008). IFN- $\gamma$-producing CD4+ and CD8+ cells are initially comparable between NYVAC, MVA, and VACV Lister but longer term studies (150 days) suggest that Lister ultimately results in higher IFN- $\gamma$-producing CD4+ cells and neutralizing antibodies. Only MVA and Lister produce neutralizing antibodies within 28 days post-vaccination, even with a NYVAC prime-boost regimen (Ferrier-Rembert et al., 2008).

The VACV B8R gene encodes a homolog of the secreted IFN- $\gamma$ receptor; loss of this gene impairs the ability of the virus to block the activity of the host cytokine, thus attenuating the virus (Verardi et al., 2001). Yet the deletion of B8R did not prevent replication of the virus in human or mouse cells in vitro. Additionally, there were no significant differences in humoral and cellular immune responses of immunocompetent mice infected with a B8R deleted-VACV or the parental virus, and despite prior studies suggesting that the B8R gene does not affect virulence of VACV in mice (Alcami and Smith, 1995a; Alcami and Smith, 1995b), the mutant caused much less morbidity in nude mice than the wt virus, even at higher doses (Denes et al., 2006).

Deletion of either of the serine protease inhibitor (serpin) genes, B13R and B22R has been shown by Legrand, et al., to attenuate VACV for replication and pathogenicity (Legrand et al., 2004). Both mutant viruses were replication-competent in murine cells, but only the B13Rdeleted virus was able to replicate in human cells. However, a later study indicated that deletion of the host immune response system modulating genes (B5R, B8R, B12R, B13R, B14R, B16R, $\mathrm{B} 18 \mathrm{R}$, and B19R) of VACV had little effect on virulence or pathogenicity and suggested that contrasting findings between this study and that of Legrand et al. may be a result of the model used (Jackson et al., 2005).

Most mutations of immune modulating genes have been analyzed in a WR background.

Recently several mutations in the VTT strain have been analyzed. The VTT strain was used to protect millions of people in the People's Republic of China from smallpox, but as with other 
strains of VACV, it is pathogenic in immune-suppressed individuals. Dai et al. deleted two non-essential immune modulatory genes, C12L (encoding an Iinterleukin-18 [IL-18] binding protein) and A53R (encoding a TNF receptor homologue) from VTT (Dai et al., 2008). Deletion of $\mathrm{C} 12 \mathrm{~L}$ resulted in a 10 -fold reduction in the intracranial (IC) lethal dose $(\mathrm{LD})_{50}$ and deletion of $\mathrm{A} 53 \mathrm{R}$ yielded a 4.6-fold reduction in the $\mathrm{IC}^{\mathrm{L}} \mathrm{D}_{50}$ in mice, while only deletion of $\mathrm{C} 12 \mathrm{~L}$ attenuated the virus in rabbits following inoculation by scarification. Deletion of the $\mathrm{C} 12 \mathrm{~L}$ gene in ectromelia virus has also been shown to be an attenuating mutation (Born et al., 2000). In a mouse model, IN inoculation of the mouse-adapted WR VACV strain deleted of C12L caused less severe symptoms when compared to the wt virus (Reading and Smith, 2003).

Mutations in the host range region of VTT have also been used to attenuate this virus. Zhu et al. (Zhu et al., 2007) deleted a fragment containing the M1L, M2L, K1L, and K2L genes. With IC inoculation of mice, this mutant virus was attenuated by 340 -fold in comparison to wild type virus. The virus was replication-incompetent in several cell lines, including HeLa (human), RK-13 (rabbit), and Vero (African green monkey). Deletion of the host range gene K1L reduces replication in RK-13 cells, and deletion of this gene along with serine protease inhibitor $\mathrm{K} 2 \mathrm{~L}$, ankyrin-like protein $\mathrm{M} 1 \mathrm{~L}$, and the early $\mathrm{M} 2 \mathrm{~L}$ gene reduces in vitro replication further. Vaccination requires a prime-boost regimen for neutralizing antibody titers and cellmediated response to approach that observed after wt VACV vaccination (Zhu et al., 2007).

Several viruses containing mutations in accessory nucleotide metabolism genes and genes encoding membrane or secreted proteins have been analyzed for attenuation and immunogenicity. Following the work done to develop vaccinia vectors to express foreign antigens in the early 1980s (Panicali et al., 1983; Smith et al., 1983a; Smith et al., 1983b), Buller, et al. showed that VACV deleted of the TK gene could replicate to normal titers locally following inoculation by scarification, but had a decreased ability to disseminate to, or replicate in internal organs (Buller et al., 1985). This virus was attenuated by 4 logs, compared to a wt control. One of the first applications for genetic engineering of VACVs was a vaccine used to combat rabies in wildlife. The gene for the rabies virus glycoprotein was inserted into VACV in place of TK (Kieny et al., 1984). Even though the TK-deleted virus is attenuated, one case of human infection was reported (Rupprecht et al., 2001), raising the issue of potential human exposure to animal vaccines and concomitant harm to humans.

In contrast to deletion of TK, deletion of ribonucleotide reductase (RR), hemaglutinin (HA) (Lee et al., 1992) or the viral growth factor (VGF) (Buller et al., 1988) affected pock formation on the skin. VACV-antibody titers for virus deleted or TK, RR or HA after high dose vaccination were similar to that achieved following vaccination with the parental viruses, but at low dose vaccinations, VACV-specific antibody levels for RR and HA deletion mutants were much lower than in animals vaccinated with wtVACV (Lee et al., 1992).

Mutations of another host range/virulence gene, E3L, has resulted in a range of attenuations of VACVs. The VACV E3L gene products prevent the induction of an antiviral state through IFN-induced pathways (Langland and Jacobs, 2002). The complete deletion of the E3L gene results in a VACV that is replication-deficient in human cells (Chang et al., 1995; Vijaysri et al., 2008). In studies in CD-1 newborn mice, the WR strain deleted of E3L was attenuated by five logs (Heck, Denzler, and Jacobs, unpublished observations). In immunocompetent mice, this virus replicates poorly in the nasal mucosa but still induces a protective immune response (Vijaysri et al., 2008) and results in increased induction of many pro-inflammatory genes compared to other mutants (Langland et al., 2006b).

Targeted mutations or deletions in either the $\mathrm{N}$-terminus or C-terminus of $\mathrm{E} 3 \mathrm{~L}$ also result in attenuated yet immunogenic versions of the parental strain, with phenotypes ranging from no 
disease to persistent infections and/or clinical disease at higher doses in SCID mice (Chang and Pogo, 1993; Jentarra et al., 2008; Langland and Jacobs, 2002; Langland and Jacobs, 2004; Vijaysri et al., 2008).

Another strategy to attenuate VACV without losing efficacy is to replace the E3L gene with a partially complementing eIF $2 \alpha$ homologue gene from Ambystoma tigrinum virus (VACV $\triangle \mathrm{E} 3 \mathrm{~L}-\mathrm{vIF} 2 \alpha$ ). VACV $\triangle \mathrm{E} 3 \mathrm{~L}-\mathrm{vIF} 2 \alpha$, is also sensitive to treatment of cells with type I interferon, a phenotype unique amongst mutants of VACV. During scarification studies, VACV $\triangle \mathrm{E} 3 \mathrm{~L}-\mathrm{vIF} 2 \alpha$ caused no significant weight loss and only localized symptoms. As a vaccine, it was protective in BALB/c mice, preventing disease, including weight loss after wtVACV challenge (Jentarra et al., 2008).

Another genetically attenuated mutant is the late defective VACV vD4-ZG, which is deleted of the essential gene that encodes the enzyme uracil DNA glycosylase (UDG) from the D4R open reading frame (Holzer and Falkner, 1997). VACV vD4-ZG is unable to produce late gene products which renders it non-replicative in cells in culture. In order to overcome this obstacle vD4-ZG must be grown in a complementing cell line that expresses the missing early viral gene (Holzer and Falkner, 1997). This non-replicating late defective mutant makes it attractive as a vaccine vector due to its ability to elicit potent immune responses through the expression of early genes. In fact, the VACV mutant expressing the prM/E gene (vD4-prME) from tickborne encephalitis (TBE) was found to protect immune-suppressed CD1 mice against a lethal challenge with $100 \mathrm{LD}_{50}$ of virulent TBE virus with just $10^{4}$ pfu of vD4-prME (Holzer et al., 1999). Furthermore, the virus was rapidly cleared from immune-suppressed mice even at the highest vaccination dose of $10^{6} \mathrm{pfu}$ (Holzer et al., 1999). However, the lack of expression of structural gene products may make this virus unsuitable as a vaccine for protection against orthopoxviruses.

\section{B. Attenuation through insertion of immune-modulating genes}

VACV has also been attenuated through the insertion of genes encoding host immune response modulators, such as IL-2 and IFN- $\gamma$. Flexner et al. demonstrated that expression of IL-2 in VACV WR strain rendered the virus non-pathogenic in athymic nude mice (Flexner et al., 1987). Virus expressing IFN- $\gamma$ was also found to be non-pathogenic in athymic nude mice (Giavedoni et al., 1992; Kohonen-Corish et al., 1990), with all mice recovering from infection. Another example is expression of IL-15 by VACVs resulting in a several-thousand-fold reduction in lethality in athymic nude mice (Perera et al., 2001), but still inducing longer-lived CD8 memory T cells (Oh et al., 2003), as well as enhanced humoral and cellular responses in immunocompetent mice compared to the unmodified virus (Perera et al., 2007). Mice vaccinated with the IL-15-expressing VACV survived a lethal IN challenge with the wt version 10 months after vaccination, whereas mice which had received a homologous vaccination succumbed (Perera et al., 2007).

Expression of immune-stimulating genes may on the other hand enhance immunogenicity of highly attenuated non-replicating VACVs. For instance, MVA has been shown to infect antigen-presenting cells, including dendritic cells, B cells, and macrophages (Chahroudi et al., 2005), which in turn activates $\mathrm{CD} 4^{+}$and $\mathrm{CD} 8^{+} \mathrm{T}$ cells and ultimately induces an antigenspecific adaptive and cell-mediated response. Therefore, expression by MVA of cytokines known to enhance activation of antigen-presenting cells could augment the overall immune response to the vaccine. Examples of such cytokines include granulocyte-macrophage colonystimulating factor, macrophage inflammatory protein $3 \alpha$, and fms-like tyrosine kinase 3 ligand, and this strategy resulted in a six- to seven-fold enhancement of MVA-specific antibody titers in a mouse experiment (Chavan et al., 2006). 
Ultimately, a combination of strategies may be needed to attenuate wt-VACV while enhancing specific immune pathways. As an example, a recombinant VACV deleted for the serpin protease inhibitors B13R or B22R but expressing IFN- $\gamma$ replicates to high titers in tissue culture but is avirulent in both immunodeficient and immunocompetent mice, and yet induces a potent VACV-specific immune response (Legrand et al., 2005).

\section{Post-exposure vaccination}

Following September 11, 2001, the potential use of the smallpox virus (VARV) as a bioterrorism agent was brought into special attention, as it constitutes an ideal terrorist weapon of mass destruction (LeDuc et al., 2002). Moreover, there also remains a low but very real risk of VARV release, whether intentional or accidental (Thorne et al., 2003). All these reasons make the requirement of a post-exposure prophylaxis of smallpox one of the ultimate goals not only nationwide but also worldwide. Post-exposure vaccination with VACV has been suggested as an effective means to minimize casualties from smallpox exposure, as long as the vaccine is administered within four days of initial exposure (Mortimer, 2003). While there is anecdotal evidence for efficacy of post-exposure vaccination, this has not been definitively studied in humans, and while no animal model of post-exposure vaccination has thus far been consistently described, several animal studies were done and are worthy of mention.

Both IN and intramuscular (IM) vaccination with MVA have been shown to protect mice from severe disease and death when mice underwent respiratory challenge with VACV WR strain after either IM or IN vaccination. However, these immunization protocols failed to completely prevent clinical signs even when given within three hours of challenge and were completely ineffective when given one to four days post-exposure. A follow-up study was done in order to compare the relative efficacy of short-term or post-exposure vaccination between the nonreplicating MVA and replication-competent VACV Lister/Elstree strain. Mice immunized by scarification with the Lister/Elstree strain 14 days prior to the challenge were protected against a respiratory challenge with VACV WR, confirming the efficacy of prophylactic vaccination, while vaccination on the same day up to two days after challenge failed to protect against mortality (Staib et al., 2006).

The lack of efficacy of the Lister/Elstree strain when given a couple of days pre- or postchallenge could be in part attributed to the route of inoculation (scarification), although IM inoculation did not improve its performance as a short-term prophylactic or therapeutic vaccine (Staib et al., 2006). Thus, post-exposure vaccination with these strains, in this particular animal model, seems to be limited.

Another study compared the effectiveness of antiviral treatment with cidofovir and a related acyclic nucleoside phosphonate analog (HPMPO-DAPy) to post-exposure vaccination using the standard dose recommended for humans of the Lister/Elstree strain of VACV after lethal monkeypox exposure. This study suggested that a multi-dose antiviral treatment within 24 hours post-infection could reduce mortality and cutaneous lesions in comparison to standard post-exposure vaccination (Stittelaar et al., 2006).

Recent studies have shown that MVA given via a subcutaneous injection at the same time as an IN lethal dose of ectromelia virus (ECTV) was able to protect mice from death and that it is able to protect TLR-9 deficient mice when administered up to two days post-challenge (Samuelsson et al., 2008). In another study, the efficacy of MVA and of the Lister/Elstree strains as post-exposure vaccines was further evaluated in mice, following IN challenge using ECTV. In this model, therapeutic immunization with the Lister/Elstree or MVA by IM provided full protection when administered the same day or one day post-infection. Moreover, protection was affected by the vaccine dose, which improved the survival rate vaccination at days two and three post-infection (Paran et al., 2009). One of the reasons that the Lister/Elstree and MVA 
vaccine are effective as post-exposure treatment against ECTV and not VACV WR may rely on the different mean time to death observed upon infection of mice after infection with either ECTV (10 days) or VACV WR (6 days) as well as the absence of neurovirulence observed in ECTV-infected mice. This extended period observed for the onset of the disease may be essential to allow time for the $\mathrm{T}$ and $\mathrm{B}$ cells to mount a solid immune response as recombination activating gene 1-deficient mice fail to confer immunity after short-term vaccination (Paran et al., 2009).

Another approach for post-exposure treatment involves the use of VACV as an expression vector for foreign genes. Because cytokines play a very important role during a VACV infection, recombinant VACV expressing cytokines have been constructed. It is known that IL-2 decreases VACV virulence, while IL-4 increases both virulence and pathogenicity in a VACV infection (Muller et al., 1994; Ramshaw et al., 1987; Sharma et al., 1996). Conversely, expression of IL-18 has been shown to clear a VACV infection when co-expressed with IL-12, indicating a synergistic action of both cytokines (Gherardi et al., 2003). Other groups of cytokines include the IFNs $\alpha$ and $\beta$, which inhibit virus replication in VACV-infected cells (Liu et al., 2004), while IFN- $\gamma$ stimulates antigen-presenting cells (Legrand et al., 2005). In a recent study, optimization of post-exposure prophylaxis in animals infected with wt VACV was successfully achieved with treatment of recombinant VACV expressing IFN- $\gamma$ at one day post infection (0\% mortality) (Holechek et al., 2008).

In conclusion, various approaches for post-exposure prophylaxis have shown some promise in being effective on preventing disease in some animal models. Although the ECTV model for post-exposure prophylaxis seems promising, a model using the more neuropathogenic WR strain could indeed be more useful when finding post-exposure treatment to a harsher onset of the disease. Future studies will determine if either replication competent or highly attenuated non-replicating VACV strains can be safely and effectively use as post-exposure prophylaxis approaches in humans.

\section{Genetically modified VACVs as vaccines against heterologous agents}

The eradication of smallpox combined with the advent of genetically engineered recombinant poxvirus technology demonstrated the feasibility of using VACVs to protect against specific pathogens. With the relative ease of generating recombinant VACVs to express heterologous genes, widespread attention has been given to the idea of using these vectors as a vehicle for an antigen delivery system against different diseases (Moss, 1996; Paoletti, 1996). To date, recombinant poxvirus vaccine vectors have been generated to target many human and veterinary infectious diseases and cancer (Perkus et al., 1995a). For nearly twenty years, VACV Cop has been utilized in a campaign to eliminate rabies in wildlife (Pastoret and Brochier, 1996). This oral based vaccine (RABORAL-V-RG®) consisting of recombinant VACV, mildly attenuated through loss of TK gene functionality, expresses the rabies glycoprotein and has been used to immunize red foxes, raccoons, coyotes and skunks in parts of the United States and Europe. This campaign has successfully eliminated rabies in parts of Europe and significantly reduced the incidence of rabies in the United States. Consequently, this vaccine is the only oral rabies vaccine licensed for use in animals in the United States and Europe (this vaccine is not licensed for use in humans) and is still currently in use.

Safety issues have been the paramount concern in VACV-based vaccine development because of complications associated with replicating wt VACVs (Perkus et al., 1995b). In an effort to circumvent the adverse effects of VACV, technology has turned to the development of highly attenuated strains of VACV and exploited the use of divergent host-restricted poxviruses in an attempt to generate a safe vaccine platform. In addition, immunization protocols such as heterologous prime/boost regimens and the co-expression of immune-modulatory molecules 
have been applied to further enhance the immune responses to these poxvirus vectors. Currently, various parameters such as mode of inoculation, routes of vaccine administration and immunization schedules are also being investigated to optimize immunization protocols and achieve efficacy and safety (Gomez et al., 2007b).

Addressing the safety issues surrounding vaccine development, extensive studies have been done using replication-deficient poxviruses as vaccine vectors. Examples of replicationdeficient poxviruses are orthopoxviruses, MVA and NYVAC, and avipoxviruses, fowlpox and canarypox (ALVAC). Both MVA and NYVAC are attenuated VACVs containing multiple gene deletions that prevent a productive replication cycle in mammalian cells, whereas avipoxviruses have a natural host range restriction and cannot replicate in non-avian cells. Preclinical studies have shown these vectors induce some level of protection against many heterologous agents when used as a vaccine in both human and veterinary medicine (Bisht et al., 2004; Bublot et al., 2007; Chen et al., 2005; Kreijtz et al., 2007; Minke et al., 2007; Poulet et al., 2007; Ramos et al., 2008). MVA and NYVAC have been studied extensively and a comprehensive review has been published comparing these vectors in detail and their various applications as vaccine vectors (Gomez et al., 2008).

Due to their safety profile and immunizing potential, both MVA and NYVAC are prime candidates in HIV vaccine development and have been used in countless preclinical and clinical trial studies (Gomez et al., 2007a), and increasing attention has turned towards using avipoxvirus vectors as safe alternatives to orthopoxvirus vectors (Thongcharoen et al., 2007). Prime-boost regimens including different combinations of these non-replicating strains have become commonplace to enhance immunity and to avoid complications with preexisting immunity to VACV vectors (Webster et al., 2005; Woodland, 2004). Despite studies that show these highly attenuated vectors are capable of inducing protective immunity against a variety of pathogens, their limited replication still generates concern as to their ability to induce an immune response as effective as their replication-competent counterparts (Abaitua et al., 2006; Dai et al., 2008; Karkhanis and Ross, 2007). Studies comparing the two vectors in vaccine studies clearly demonstrate that in an effort for safety, often long term protection and efficacy are lost. For instance, in a quest for a safer rabies vaccine, a recent study compared the efficacies of various rabies vaccine candidates in different VACV strains. Recombinant MVA proved to be inferior in mounting an immune response in mice when given by oral immunization compared to Cop and WR strain. Furthermore, oral administration of this vector failed to elicit memory responses in previously vaccinated dogs and raccoons and was therefore deemed not suitable for a replacement of the current oral vaccine, V-RG (Weyer et al., 2007). In addition, a recent smallpox vaccine study has further emphasized the superiority of replication competent vectors to non replicating vectors in long term protection and immunogenicity against lethal cowpox challenge (Ferrier-Rembert et al., 2008).

Replication-competent recombinant VACV-based vaccines have received increasing attention as potential vaccine vectors for many infectious diseases, since they are presumably able to elicit potent humoral and cell mediated immune responses, and confer lasting protection. Different approaches have been taken to lower the virulence and enhance the immune response in an effort to generate a safe vaccine platform. Many have turned to deleting genes encoding virulence factors whose function is to evade the host immune response. Examples include soluble cytokine/chemokine viroceptors (Day et al., 2008; Denes et al., 2006; Symons et al., 1995), viral serine protease inhibitors (serpin) (Legrand et al., 2004), and inhibitors of cellular antiviral enzymes (Langland et al., 2006a). Immunogenicity of vectors attenuated through deletion of these genes was not greatly affected. In two independent studies, the deletion of the B8R gene (Denes et al., 2006; Verardi et al., 2001) resulted in a virus able to replicate at the same level as the wt version in vitro, yet was significantly less pathogenic in mice than the 
latter. Immunologic responses between the deletion mutant and parental virus were analyzed and no substantial differences were observed.

In another study, deletion of the IL-18 binding protein C12L and the viral TNF receptor homologue A53R resulted in a virus that was attenuated, yet virus that expressed HIV genes was able to elicit a strong humoral and cell-mediated response to HIV proteins (Dai et al., 2008). Another example of attenuation by reduction of virulence factor functionality is the work performed by our group with E3L, as previously discussed (Jentarra et al., 2008; Langland and Jacobs, 2002; Langland and Jacobs, 2004; Langland et al., 2006b; Vijaysri et al., 2008). VACV deleted of serpin proteins B13R and B22R expressing IFN- $\gamma$ is highly attenuated in immunocompromised mice and elicits potent immune responses and protection against challenge of both homologous and heterologous agents (Legrand et al., 2005). Collectively, these live vaccine vectors represent a promising potential as safe effective vaccine platforms.

\section{Conclusion}

Many of the genetically modified poxviruses are replication-defective, a characteristic which has long been considered critical in developing safe vaccines in an era of immune deficiency resulting from chemotherapy, organ transplant, HIV infection, or other diseases impacting the immune system. Unfortunately, recent animal and limited human data suggest that "third and fourth generation" replication-defective VACV vaccines are in fact less immunogenic than prior vaccine generations, although these vaccines may have utility as priming agents in individuals with contraindications to "second generation" vaccines (Artenstein, 2008). However, the necessity for replication-competence in vaccine vectors has become an increasingly theorized potential solution to the lack of efficacy in some of the vaccines that have been tested in human trials recently. One of the most scrutinized of these unsuccessful trials was that of the Merck HIV vaccine that used a replication-defective adenovirus vector for delivery of the HIV antigens (http://www.hvtn.org/science/step_review.html). Replication competence does not exclude attenuation, as was evidenced in a report by Parker et al. (Parker et al., 2007). In this study, a recombinant herpes simplex virus (HSV) was attenuated by deletion of the $\gamma 34.5$ gene, which eliminated neurovirulence; the virus was still replicationcompetent. The virus can be grown to higher titers than a replication-defective HSV vector and expresses the heterologous antigens at higher levels. Therefore, "third generation" attenuated replication-competent vaccine candidates are being developed to provide a strong immunological response while reducing adverse side-effects.

VACV encodes a number of proteins involved in inhibiting the host anti-viral, immunological and inflammatory responses. Mutagenesis or deletion of these genes often leads to viral constructs which are replication-competent but with reduced pathogenesis. For example, the viral E3L gene is required for inhibition of the host in IFN response. As discussed in this review, mutations of this gene in VACVs resulted in several replication-competent viruses with greatly reduced virulence in animals, which retained the ability to protect against an orthopoxvirus challenge (Vijaysri et al., 2008). Similarly, attenuated replication-competent vaccines constructed by the addition of genes to the VACV genome, such as IL-15 or IFN- $\gamma$ are known to effectively modulate the host responses and improve immunogenicity (Legrand et al., 2005; Perera et al., 2007). Finally, VACV having the E3L gene replaced with the vIF2 $\alpha$, which allows for a single round of replication in human cells, is not capable of dissemination but does activate immune response signal transduction pathways (Jancovich, Langland, Talasela and Jacobs, unpublished observations). Therefore, we are confident that continued efforts to genetically modify poxvirus vectors will not only improve our understanding of these viruses but also allow preservation of safety while taking advantage of the immunogenic benefits of replication competence. 


\section{Acknowledgments}

The authors would like to thank Mike Bray for his helpful editorial comments, encouragement, and patience.

\section{Bibliography}

Products, CfPMPTEAftEoM, editor. Note for Guidance on the Development of Vaccinia Virus Based Vaccines Against Smallpox, Evaluation of Medicines for Human Use. 2002. p. 1-19.

Abaitua F, Rodriguez JR, Garzon A, Rodriguez D, Esteban M. Improving recombinant MVA immune responses: potentiation of the immune responses to HIV-1 with MVA and DNA vectors expressing Env and the cytokines IL-12 and IFN-gamma. Virus Res 2006;116(1-2):11-20. [PubMed: 16214252]

Abdalrhman I, Gurt I, Katz E. Protection induced in mice against a lethal orthopox virus by the Lister strain of vaccinia virus and modified vaccinia virus Ankara (MVA). Vaccine 2006;24(19):4152-60. [PubMed: 16603280]

Alcami A, Smith GL. Cytokine receptors encoded by poxviruses: a lesson in cytokine biology. Immunol Today 1995a;16(10):474-8. [PubMed: 7576050]

Alcami A, Smith GL. Vaccinia, cowpox, and camelpox viruses encode soluble gamma interferon receptors with novel broad species specificity. J Virol 1995b;69(8):4633-9. [PubMed: 7609027]

Antoine G, Scheiflinger F, Dorner F, Falkner FG. The complete genomic sequence of the modified vaccinia Ankara strain: comparison with other orthopoxviruses. Virology 1998;244(2):365-96. [PubMed: 9601507]

Artenstein AW. New generation smallpox vaccines: a review of preclinical and clinical data. Rev Med Virol 2008;18(4):217-31. [PubMed: 18283712]

Bell E, Shamim M, Whitbeck JC, Sfyroera G, Lambris JD, Isaacs SN. Antibodies against the extracellular enveloped virus B5R protein are mainly responsible for the EEV neutralizing capacity of vaccinia immune globulin. Virology 2004;325(2):425-31. [PubMed: 15246280]

Belyakov IM, Earl P, Dzutsev A, Kuznetsov VA, Lemon M, Wyatt LS, Snyder JT, Ahlers JD, Franchini G, Moss B, Berzofsky JA. Shared modes of protection against poxvirus infection by attenuated and conventional smallpox vaccine viruses. Proc Natl Acad Sci U S A 2003;100(16):9458-63. [PubMed: 12869693]

Bisht H, Roberts A, Vogel L, Bukreyev A, Collins PL, Murphy BR, Subbarao K, Moss B. Severe acute respiratory syndrome coronavirus spike protein expressed by attenuated vaccinia virus protectively immunizes mice. Proc Natl Acad Sci U S A 2004;101(17):6641-6. [PubMed: 15096611]

Blanchard TJ, Alcami A, Andrea P, Smith GL. Modified vaccinia virus Ankara undergoes limited replication in human cells and lacks several immunomodulatory proteins: implications for use as a human vaccine. J Gen Virol 1998;79 (Pt 5):1159-67. [PubMed: 9603331]

Born TL, Morrison LA, Esteban DJ, VandenBos T, Thebeau LG, Chen N, Spriggs MK, Sims JE, Buller RM. A poxvirus protein that binds to and inactivates IL-18, and inhibits NK cell response. J Immunol 2000;164(6):3246-54. [PubMed: 10706717]

Brandt T, Heck MC, Vijaysri S, Jentarra GM, Cameron JM, Jacobs BL. The N-terminal domain of the vaccinia virus E3L-protein is required for neurovirulence, but not induction of a protective immune response. Virology 2005;333(2):263-70. [PubMed: 15721360]

Bublot M, Pritchard N, Cruz JS, Mickle TR, Selleck P, Swayne DE. Efficacy of a fowlpox-vectored avian influenza $\mathrm{H} 5$ vaccine against Asian H5N1 highly pathogenic avian influenza virus challenge. Avian Dis 2007;51(1 Suppl):498-500. [PubMed: 17494618]

Buller RM, Chakrabarti S, Cooper JA, Twardzik DR, Moss B. Deletion of the vaccinia virus growth factor gene reduces virus virulence. J Virol 1988;62(3):866-74. [PubMed: 3339716]

Buller RM, Smith GL, Cremer K, Notkins AL, Moss B. Decreased virulence of recombinant vaccinia virus expression vectors is associated with a thymidine kinase-negative phenotype. Nature 1985;317 (6040):813-5. [PubMed: 4058585]

Chahroudi A, Chavan R, Kozyr N, Waller EK, Silvestri G, Feinberg MB. Vaccinia virus tropism for primary hematolymphoid cells is determined by restricted expression of a unique virus receptor. $\mathrm{J}$ Virol 2005;79(16):10397-407. [PubMed: 16051832] 
Chahroudi A, Garber DA, Reeves P, Liu L, Kalman D, Feinberg MB. Differences and similarities in viral life cycle progression and host cell physiology after infection of human dendritic cells with modified vaccinia virus Ankara and vaccinia virus. J Virol 2006;80(17):8469-81. [PubMed: 16912297]

Chang HW, Uribe LH, Jacobs BL. Rescue of vaccinia virus lacking the E3L gene by mutants of E3L. J Virol 1995;69(10):6605-8. [PubMed: 7666567]

Chang PY, Pogo BG. Reintroduction of gene(s) into an attenuated deletion mutant of vaccinia virus strain IHD-W. Microb Pathog 1993;15(5):347-57. [PubMed: 8015416]

Chavan R, Marfatia KA, An IC, Garber DA, Feinberg MB. Expression of CCL20 and granulocytemacrophage colony-stimulating factor, but not Flt3-L, from modified vaccinia virus ankara enhances antiviral cellular and humoral immune responses. J Virol 2006;80(15):7676-87. [PubMed: 16840346]

Chen Z, Zhang L, Qin C, Ba L, Yi CE, Zhang F, Wei Q, He T, Yu W, Yu J, Gao H, Tu X, Gettie A, Farzan M, Yuen KY, Ho DD. Recombinant modified vaccinia virus Ankara expressing the spike glycoprotein of severe acute respiratory syndrome coronavirus induces protective neutralizing antibodies primarily targeting the receptor binding region. J Virol 2005;79(5):2678-88. [PubMed: 15708987]

Clark RH, Kenyon JC, Bartlett NW, Tscharke DC, Smith GL. Deletion of gene A41L enhances vaccinia virus immunogenicity and vaccine efficacy. J Gen Virol 2006;87(Pt 1):29-38. [PubMed: 16361415]

Cottingham MG, Andersen RF, Spencer AJ, Saurya S, Furze J, Hill AV, Gilbert SC. Recombinationmediated genetic engineering of a bacterial artificial chromosome clone of modified vaccinia virus Ankara (MVA). PLoS ONE 2008;3(2):e1638. [PubMed: 18286194]

Couch RB, Winokur P, Edwards KM, Black S, Atmar RL, Stapleton JT, Kissner JM, Shinefield H, Denny TN, Bybel MJ, Newman FK, Yan L. Reducing the dose of smallpox vaccine reduces vaccineassociated morbidity without reducing vaccination success rates or immune responses. J Infect Dis 2007;195(6):826-32. [PubMed: 17299712]

Dai K, Liu Y, Liu M, Xu J, Huang W, Huang X, Liu L, Wan Y, Hao Y, Shao Y. Pathogenicity and immunogenicity of recombinant Tiantan Vaccinia Virus with deleted C12L and A53R genes. Vaccine. 2008

Davies DH, Wyatt LS, Newman FK, Earl PL, Chun S, Hernandez JE, Molina DM, Hirst S, Moss B, Frey SE, Felgner PL. Antibody profiling by proteome microarray reveals the immunogenicity of the attenuated smallpox vaccine modified vaccinia virus ankara is comparable to that of Dryvax. J Virol 2008;82(2):652-63. [PubMed: 17977963]

Day SL, Ramshaw IA, Ramsay AJ, Ranasinghe C. Differential effects of the type I interferons alpha4, beta, and epsilon on antiviral activity and vaccine efficacy. J Immunol 2008;180(11):7158-66. [PubMed: 18490714]

Denes B, Gridley DS, Fodor N, Takatsy Z, Timiryasova TM, Fodor I. Attenuation of a vaccine strain of vaccinia virus via inactivation of interferon viroceptor. J Gene Med 2006;8(7):814-23. [PubMed: 16634110]

Downie AW, McCarthy K. The antibody response in man following infection with viruses of the pox group. III. Antibody response in smallpox. J Hyg (Lond) 1958;56(4):479-87. [PubMed: 13611244]

Earl PL, Americo JL, Wyatt LS, Eller LA, Whitbeck JC, Cohen GH, Eisenberg RJ, Hartmann CJ, Jackson DL, Kulesh DA, Martinez MJ, Miller DM, Mucker EM, Shamblin JD, Zwiers SH, Huggins JW, Jahrling PB, Moss B. Immunogenicity of a highly attenuated MVA smallpox vaccine and protection against monkeypox. Nature 2004;428(6979):182-5. [PubMed: 15014500]

Earl PL, Americo JL, Wyatt LS, Espenshade O, Bassler J, Gong K, Lin S, Peters E, Rhodes L Jr, Spano YE, Silvera PM, Moss B. Rapid protection in a monkeypox model by a single injection of a replication-deficient vaccinia virus. Proc Natl Acad Sci U S A 2008;105(31):10889-94. [PubMed: 18678911]

Fang Q, Yang L, Zhu W, Liu L, Wang H, Yu W, Xiao G, Tien P, Zhang L, Chen Z. Host range, growth property, and virulence of the smallpox vaccine: vaccinia virus Tian Tan strain. Virology 2005;335 (2):242-51. [PubMed: 15840523]

Fenner, F.; Henderson, DA.; Arita, I.; Jezek, Z.; Ladnyi, ID. Smallpox and its Eradication. World Health Organization; Geneva: 1988. p. 1460 
Ferrier-Rembert A, Drillien R, Tournier JN, Garin D, Crance JM. Short-and long-term immunogenicity and protection induced by non-replicating smallpox vaccine candidates in mice and comparison with the traditional 1st generation vaccine. Vaccine 2008;26(14):1794-804. [PubMed: 18336966]

Flexner C, Hugin A, Moss B. Prevention of vaccinia virus infection in immunodeficient mice by vectordirected IL-2 expression. Nature 1987;330(6145):259-62. [PubMed: 3118219]

Frey SE, Newman FK, Kennedy JS, Sobek V, Ennis FA, Hill H, Yan LK, Chaplin P, Vollmar J, Chaitman BR, Belshe RB. Clinical and immunologic responses to multiple doses of IMVAMUNE (Modified Vaccinia Ankara) followed by Dryvax challenge. Vaccine 2007;25(51):8562-73. [PubMed: 18036708]

Gherardi MM, Ramirez JC, Esteban M. IL-12 and IL-18 act in synergy to clear vaccinia virus infection: involvement of innate and adaptive components of the immune system. J Gen Virol 2003;84(Pt 8): 1961-72. [PubMed: 12867626]

Giavedoni LD, Jones L, Gardner MB, Gibson HL, Ng CT, Barr PJ, Yilma T. Vaccinia virus recombinants expressing chimeric proteins of human immunodeficiency virus and gamma interferon are attenuated for nude mice. Proc Natl Acad Sci U S A 1992;89(8):3409-13. [PubMed: 1565633]

Gomez CE, Najera JL, Jimenez EP, Jimenez V, Wagner R, Graf M, Frachette MJ, Liljestrom P, Pantaleo G, Esteban M. Head-to-head comparison on the immunogenicity of two HIV/AIDS vaccine candidates based on the attenuated poxvirus strains MVA and NYVAC co-expressing in a single locus the HIV-1BX08 gp120 and HIV-1(IIIB) Gag-Pol-Nef proteins of clade B. Vaccine 2007a;25 (15):2863-85. [PubMed: 17113200]

Gomez CE, Najera JL, Jimenez V, Bieler K, Wild J, Kostic L, Heidari S, Chen M, Frachette MJ, Pantaleo G, Wolf H, Liljestrom P, Wagner R, Esteban M. Generation and immunogenicity of novel HIV/AIDS vaccine candidates targeting HIV-1 Env/Gag-Pol-Nef antigens of clade C. Vaccine 2007b;25(11): 1969-92. [PubMed: 17224219]

Gomez CE, Najera JL, Krupa M, Esteban M. The poxvirus vectors MVA and NYVAC as gene delivery systems for vaccination against infectious diseases and cancer. Curr Gene Ther 2008;8(2):97-120. [PubMed: 18393831]

Greenberg RN, Kennedy JS. ACAM2000: a newly licensed cell culture-based live vaccinia smallpox vaccine. Expert Opin Investig Drugs 2008;17(4):555-64.

Guerra S, Najera JL, Gonzalez JM, Lopez-Fernandez LA, Climent N, Gatell JM, Gallart T, Esteban M. Distinct gene expression profiling after infection of immature human monocyte-derived dendritic cells by the attenuated poxvirus vectors MVA and NYVAC. J Virol 2007;81(16):8707-21. [PubMed: 17537851]

Hayasaka D, Ennis FA, Terajima M. Pathogeneses of respiratory infections with virulent and attenuated vaccinia viruses. Virol J 2007;4:22. [PubMed: 17326843]

Herrera E, Lorenzo MM, Blasco R, Isaacs SN. Functional analysis of vaccinia virus B5R protein: essential role in virus envelopment is independent of a large portion of the extracellular domain. J Virol 1998;72(1):294-302. [PubMed: 9420227]

Holechek, S.; Heck, M.; Yilma, T.; Buller, RM.; Jacobs, B. Effects of a vaccinia virus expressing IFNgamma on the post-exposure prophylaxis of a lethal vaccinia virus infection. 17th International poxvirus and iridovirus conference; Grainau (Bavaria), Germany. 2008.

Holzer GW, Falkner FG. Construction of a vaccinia virus deficient in the essential DNA repair enzyme uracil DNA glycosylase by a complementing cell line. J Virol 1997;71(7):4997-5002. [PubMed: 9188564]

Holzer GW, Remp G, Antoine G, Pfleiderer M, Enzersberger OM, Emsenhuber W, Hammerle T, Gruber F, Urban C, Falkner FG, Dorner F. Highly efficient induction of protective immunity by a vaccinia virus vector defective in late gene expression. J Virol 1999;73(6):4536-42. [PubMed: 10233911]

Ishii K, Ueda Y, Matsuo K, Matsuura Y, Kitamura T, Kato K, Izumi Y, Someya K, Ohsu T, Honda M, Miyamura T. Structural analysis of vaccinia virus DIs strain: application as a new replicationdeficient viral vector. Virology 2002;302(2):433-44. [PubMed: 12441087]

Jackson SS, Ilyinskii P, Philippon V, Gritz L, Yafal AG, Zinnack K, Beaudry KR, Manson KH, Lifton MA, Kuroda MJ, Letvin NL, Mazzara GP, Panicali DL. Role of genes that modulate host immune responses in the immunogenicity and pathogenicity of vaccinia virus. J Virol 2005;79(10):6554-9. [PubMed: 15858042] 
Jentarra GM, Heck MC, Youn JW, Kibler K, Langland JO, Baskin CR, Ananieva O, Chang Y, Jacobs BL. Vaccinia viruses with mutations in the E3L gene as potential replication-competent, attenuated vaccines: scarification vaccination. Vaccine 2008;26(23):2860-72. [PubMed: 18455281]

Karkhanis LU, Ross TM. Mucosal vaccine vectors: replication-competent versus replication-deficient poxviruses. Curr Pharm Des 2007;13(19):2015-23. [PubMed: 17627535]

Kennedy JS, Greenberg RN. IMVAMUNE: modified vaccinia Ankara strain as an attenuated smallpox vaccine. Expert Rev Vaccines 2009;8(1):13-24. [PubMed: 19093767]

Kenner J, Cameron F, Empig C, Jobes DV, Gurwith M. LC16m8: an attenuated smallpox vaccine. Vaccine 2006;24(47-48):7009-22. [PubMed: 17052815]

Kidokoro M, Tashiro M, Shida H. Genetically stable and fully effective smallpox vaccine strain constructed from highly attenuated vaccinia LC16m8. Proc Natl Acad Sci U S A 2005;102(11):41527. [PubMed: 15753319]

Kieny MP, Lathe R, Drillien R, Spehner D, Skory S, Schmitt D, Wiktor T, Koprowski H, Lecocq JP. Expression of rabies virus glycoprotein from a recombinant vaccinia virus. Nature 1984;312(5990): 163-6. [PubMed: 6548799]

Kohonen-Corish MR, King NJ, Woodhams CE, Ramshaw IA. Immunodeficient mice recover from infection with vaccinia virus expressing interferon-gamma. Eur J Immunol 1990;20(1):157-61. [PubMed: 2106440]

Kreijtz JH, Suezer Y, van Amerongen G, de Mutsert G, Schnierle BS, Wood JM, Kuiken T, Fouchier RA, Lower J, Osterhaus AD, Sutter G, Rimmelzwaan GF. Recombinant modified vaccinia virus Ankara-based vaccine induces protective immunity in mice against infection with influenza virus H5N1. J Infect Dis 2007;195(11):1598-606. [PubMed: 17471429]

Kretzschmar M, Wallinga J, Teunis P, Xing S, Mikolajczyk R. Frequency of adverse events after vaccination with different vaccinia strains. PLoS Med 2006;3(8):e272. [PubMed: 16933957]

Langland JO, Cameron JM, Heck MC, Jancovich JK, Jacobs BL. Inhibition of PKR by RNA and DNA viruses. Virus Res 2006;119(1):100-10. [PubMed: 16704884]

Langland JO, Jacobs BL. The role of the PKR-inhibitory genes, E3L and K3L, in determining vaccinia virus host range. Virology 2002;299(1):133-41. [PubMed: 12167348]

Langland JO, Jacobs BL. Inhibition of PKR by vaccinia virus: role of the $\mathrm{N}$-and C-terminal domains of E3L. Virology 2004;324(2):419-29. [PubMed: 15207627]

Langland JO, Kash JC, Carter V, Thomas MJ, Katze MG, Jacobs BL. Suppression of proinflammatory signal transduction and gene expression by the dual nucleic acid binding domains of the vaccinia virus E3L proteins. J Virol 2006;80(20):10083-95. [PubMed: 17005686]

Larsson M, Fonteneau JF, Somersan S, Sanders C, Bickham K, Thomas EK, Mahnke K, Bhardwaj N. Efficiency of cross presentation of vaccinia virus-derived antigens by human dendritic cells. Eur J Immunol 2001;31(12):3432-42. [PubMed: 11745362]

LeDuc JW, Damon I, Relman DA, Huggins J, Jahrling PB. Smallpox research activities: U.S. interagency collaboration, 2001. Emerg Inf Dis 2002;8(7):743-45.

Lee MS, Roos JM, McGuigan LC, Smith KA, Cormier N, Cohen LK, Roberts BE, Payne LG. Molecular attenuation of vaccinia virus: mutant generation and animal characterization. J Virol 1992;66(5): 2617-30. [PubMed: 1560521]

Legrand FA, Verardi PH, Chan KS, Peng Y, Jones LA, Yilma TD. Vaccinia viruses with a serpin gene deletion and expressing IFN-gamma induce potent immune responses without detectable replication in vivo. Proc Natl Acad Sci U S A 2005;102(8):2940-5. [PubMed: 15705716]

Legrand FA, Verardi PH, Jones LA, Chan KS, Peng Y, Yilma TD. Induction of potent humoral and cellmediated immune responses by attenuated vaccinia virus vectors with deleted serpin genes. J Virol 2004;78(6):2770-9. [PubMed: 14990697]

Lehmann MH, Kastenmuller W, Kandemir JD, Brandt F, Suezer Y, Sutter G. Modified vaccinia virus ankara triggers chemotaxis of monocytes and early respiratory immigration of leukocytes by induction of CCL2 expression. J Virol 2009;83(6):2540-52. [PubMed: 19129447]

Liu G, Zhai Q, Schaffner DJ, Wu A, Yohannes A, Robinson TM, Maland M, Wells J, Voss TG, Bailey $\mathrm{C}$, Alibek K. Prevention of lethal respiratory vaccinia infections in mice with interferon-alpha and interferon-gamma. FEMS Immunol Med Microbiol 2004;40(3):201-6. [PubMed: 15039095] 
Ludwig H, Mages J, Staib C, Lehmann MH, Lang R, Sutter G. Role of viral factor E3L in modified vaccinia virus ankara infection of human HeLa Cells: regulation of the virus life cycle and identification of differentially expressed host genes. J Virol 2005;79(4):2584-96. [PubMed: 15681458]

Mack TM, Noble J Jr, Thomas DB. A prospective study of serum antibody and protection against smallpox. Am J Trop Med Hyg 1972;21(2):214-8. [PubMed: 5061278]

Marriott KA, Parkinson CV, Morefield SI, Davenport R, Nichols R, Monath TP. Clonal vaccinia virus grown in cell culture fully protects monkeys from lethal monkeypox challenge. Vaccine 2008;26(4): 581-8. [PubMed: 18077063]

Mayr A. Smallpox vaccination and bioterrorism with pox viruses. Comp Immunol Microbiol Infect Dis 2003;26(5-6):423-30. [PubMed: 12818626]

McCurdy LH, Larkin BD, Martin JE, Graham BS. Modified vaccinia Ankara: potential as an alternative smallpox vaccine. Clin Infect Dis 2004;38(12):1749-53. [PubMed: 15227622]

Meng X, Chao J, Xiang Y. Identification from diverse mammalian poxviruses of host-range regulatory genes functioning equivalently to vaccinia virus C7L. Virology 2008;372(2):372-83. [PubMed: 18054061]

Meseda CA, Garcia AD, Kumar A, Mayer AE, Manischewitz J, King LR, Golding H, Merchlinsky M, Weir JP. Enhanced immunogenicity and protective effect conferred by vaccination with combinations of modified vaccinia virus Ankara and licensed smallpox vaccine Dryvax in a mouse model. Virology 2005;339(2):164-75. [PubMed: 15993917]

Meyer H, Sutter G, Mayr A. Mapping of deletions in the genome of the highly attenuated vaccinia virus MVA and their influence on virulence. J Gen Virol 1991;72 (Pt 5):1031-8. [PubMed: 2033387]

Miller JD, van der Most RG, Akondy RS, Glidewell JT, Albott S, Masopust D, Murali-Krishna K, Mahar PL, Edupuganti S, Lalor S, Germon S, Del Rio C, Mulligan MJ, Staprans SI, Altman JD, Feinberg MB, Ahmed R. Human effector and memory CD8+ T cell responses to smallpox and yellow fever vaccines.[see comment]. Immunity 2008;28(5):710-22. [PubMed: 18468462]

Minke JM, Toulemonde CE, Coupier H, Guigal PM, Dinic S, Sindle T, Jessett D, Black L, Bublot M, Pardo MC, Audonnet JC. Efficacy of a canarypox-vectored recombinant vaccine expressing the hemagglutinin gene of equine influenza $\mathrm{H} 3 \mathrm{~N} 8$ virus in the protection of ponies from viral challenge. Am J Vet Res 2007;68(2):213-9. [PubMed: 17269889]

Monath TP. Yellow fever vaccine. Expert Rev Vaccines 2005;4(4):553-74. [PubMed: 16117712]

Morikawa S, Sakiyama T, Hasegawa H, Saijo M, Maeda A, Kurane I, Maeno G, Kimura J, Hirama C, Yoshida T, Asahi-Ozaki Y, Sata T, Kurata T, Kojima A. An attenuated LC16m8 smallpox vaccine: analysis of full-genome sequence and induction of immune protection. J Virol 2005;79(18):1187391. [PubMed: 16140764]

Mortimer PP. Can postexposure vaccination against smallpox succeed? Clin Infect Dis 2003;36(5):6229. [PubMed: 12594644]

Moss B. Genetically engineered poxviruses for recombinant gene expression, vaccination, and safety. Proc Natl Acad Sci U S A 1996;93(21):11341-8. [PubMed: 8876137]

Muller U, Steinhoff U, Reis LF, Hemmi S, Pavlovic J, Zinkernagel RM, Aguet M. Functional role of type I and type II interferons in antiviral defense. Science 1994;264(5167):1918-21. [PubMed: 8009221]

Najera JL, Gomez CE, Domingo-Gil E, Gherardi MM, Esteban M. Cellular and biochemical differences between two attenuated poxvirus vaccine candidates (MVA and NYVAC) and role of the C7L gene. J Virol 2006;80(12):6033-47. [PubMed: 16731942]

Neff J, Modlin J, Birkhead GS, Poland G, Robertson RM, Sepkowitz K, Yancy C, Gardner P, Gray GC, Maurer T, Siegel J, Guerra FA, Berger T, Flanders WD, Shope R. Monitoring the safety of a smallpox vaccination program in the United States: report of the joint Smallpox Vaccine Safety Working Group of the advisory committee on immunization practices and the Armed Forces Epidemiological Board. Clin Infect Dis 2008;46(Suppl 3):S258-70. [PubMed: 18284367]

Oguiura N, Spehner D, Drillien R. Detection of a protein encoded by the vaccinia virus C7L open reading frame and study of its effect on virus multiplication in different cell lines. J Gen Virol 1993;74 (Pt 7):1409-13. [PubMed: 8336123] 
Oh S, Berzofsky JA, Burke DS, Waldmann TA, Perera LP. Coadministration of HIV vaccine vectors with vaccinia viruses expressing IL-15 but not IL-2 induces long-lasting cellular immunity. Proc Natl Acad Sci U S A 2003;100(6):3392-7. [PubMed: 12626740]

Panicali D, Davis SW, Weinberg RL, Paoletti E. Construction of live vaccines by using genetically engineered poxviruses: biological activity of recombinant vaccinia virus expressing influenza virus hemagglutinin. Proc Natl Acad Sci U S A 1983;80(17):5364-8. [PubMed: 6310573]

Paoletti E. Applications of pox virus vectors to vaccination: an update. Proc Natl Acad Sci U S A 1996;93 (21):11349-53. [PubMed: 8876138]

Paoletti E, Tartaglia J, Taylor J. Safe and effective poxvirus vectors--NYVAC and ALVAC. Dev Biol Stand 1994;82:65-9. [PubMed: 7958484]

Paran N, Suezer Y, Lustig S, Israely T, Schwantes A, Melamed S, Katz L, Preuss T, Hanschmann KM, Kalinke U, Erez N, Levin R, Velan B, Lower J, Shafferman A, Sutter G. Postexposure Immunization with Modified Vaccinia Virus Ankara or Conventional Lister Vaccine Provides Solid Protection in a Murine Model of Human Smallpox. J Infect Dis 2009;199(1):39-48. [PubMed: 19012492]

Parker SD, Rottinghaus ST, Zajac AJ, Yue L, Hunter E, Whitley RJ, Parker JN. HIV-1(89.6) Gag expressed from a replication competent HSV-1 vector elicits persistent cellular immune responses in mice. Vaccine 2007;25(37-38):6764-73. [PubMed: 17706843]

Parrino J, Graham BS. Smallpox vaccines: Past, present, and future. J Allergy Clin Immunol 2006;118 (6):1320-6. [PubMed: 17157663]

Pastoret PP, Brochier B. The development and use of a vaccinia-rabies recombinant oral vaccine for the control of wildlife rabies; a link between Jenner and Pasteur. Epidemiol Infect 1996;116(3):235-40. [PubMed: 8666066]

Perera LP, Goldman CK, Waldmann TA. Comparative assessment of virulence of recombinant vaccinia viruses expressing IL-2 and IL-15 in immunodeficient mice. Proc Natl Acad Sci U S A 2001;98(9): 5146-51. [PubMed: 11296252]

Perera LP, Waldmann TA, Mosca JD, Baldwin N, Berzofsky JA, Oh SK. Development of smallpox vaccine candidates with integrated interleukin-15 that demonstrate superior immunogenicity, efficacy, and safety in mice. J Virol 2007;81(16):8774-83. [PubMed: 17553867]

Perkus ME, Goebel SJ, Davis SW, Johnson GP, Limbach K, Norton EK, Paoletti E. Vaccinia virus host range genes. Virology 1990;179(1):276-86. [PubMed: 2171207]

Perkus ME, Tartaglia J, Paoletti E. Poxvirus-based vaccine candidates for cancer, AIDS, and other infectious diseases. J Leukoc Biol 1995a;58(1):1-13. [PubMed: 7616101]

Perkus ME, Taylor J, Tartaglia J, Pincus S, Kauffman EB, Tine JA, Paoletti E. Live attenuated vaccinia and other poxviruses as delivery systems: public health issues. Ann N Y Acad Sci 1995b;754:22233. [PubMed: 7625655]

Poulet H, Minke J, Pardo MC, Juillard V, Nordgren B, Audonnet JC. Development and registration of recombinant veterinary vaccines. The example of the canarypox vector platform. Vaccine 2007;25 (30):5606-12. [PubMed: 17227690]

Radetsky M. Smallpox: a history of its rise and fall. Pediatr Infect Dis J 1999;18(2):85-93. [PubMed: 10048677]

Ramos I, Alonso A, Marcen JM, Peris A, Castillo JA, Colmenares M, Larraga V. Heterologous primeboost vaccination with a non-replicative vaccinia recombinant vector expressing LACK confers protection against canine visceral leishmaniasis with a predominant Th1-specific immune response. Vaccine 2008;26(3):333-44. [PubMed: 18093705]

Ramshaw IA, Andrew ME, Phillips SM, Boyle DB, Coupar BE. Recovery of immunodeficient mice from a vaccinia virus/IL-2 recombinant infection. Nature 1987;329(6139):545-6. [PubMed: 3498904]

Reading PC, Smith GL. Vaccinia virus interleukin-18-binding protein promotes virulence by reducing gamma interferon production and natural killer and T-cell activity. J Virol 2003;77(18):9960-8. [PubMed: 12941906]

Rosenthal SR, Merchlinsky M, Kleppinger C, Goldenthal KL. Developing new smallpox vaccines. Emerg Infect Dis 2001;7(6):920-6. [PubMed: 11747717]

Rotz LD, Dotson DA, Damon IK, Becher JA. Vaccinia (smallpox) vaccine: recommendations of the Advisory Committee on Immunization Practices (ACIP), 2001. MMWR Recomm Rep 2001;50 (RR10):1-25. [PubMed: 15580803]quiz CE1-7 
Rupprecht CE, Blass L, Smith K, Orciari LA, Niezgoda M, Whitfield SG, Gibbons RV, Guerra M, Hanlon CA. Human infection due to recombinant vaccinia-rabies glycoprotein virus. N Engl J Med 2001;345(8):582-6. [PubMed: 11529212]

Samuelsson C, Hausmann J, Lauterbach H, Schmidt M, Akira S, Wagner H, Chaplin P, Suter M, O'Keeffe M, Hochrein H. Survival of lethal poxvirus infection in mice depends on TLR9, and therapeutic vaccination provides protection. J Clin Invest 2008;118(5):1776-84. [PubMed: 18398511]

Sharma DP, Ramsay AJ, Maguire DJ, Rolph MS, Ramshaw IA. Interleukin-4 mediates down regulation of antiviral cytokine expression and cytotoxic T-lymphocyte responses and exacerbates vaccinia virus infection in vivo. J Virol 1996;70(10):7103-7. [PubMed: 8794356]

Sharon M, Nir P, Lior K, David BN, Tomer I, Paula S, Reuven L, Shlomo L. Tail scarification with Vaccinia virus Lister as a model for evaluation of smallpox vaccine potency in mice. Vaccine 2007;25(45):7743-53. [PubMed: 17928110]

Smith GL, Mackett M, Moss B. Infectious vaccinia virus recombinants that express hepatitis B virus surface antigen. Nature 1983a;302(5908):490-5. [PubMed: 6835382]

Smith GL, Murphy BR, Moss B. Construction and characterization of an infectious vaccinia virus recombinant that expresses the influenza hemagglutinin gene and induces resistance to influenza virus infection in hamsters. Proc Natl Acad Sci U S A 1983b;80(23):7155-9. [PubMed: 6580632]

Sniadack MM, Neff LJ, Swerdlow DL, Schieber RA, McCauley MM, Mootrey GT. Follow-up of cardiovascular adverse events after smallpox vaccination among civilians in the United States, 2003. Clin Infect Dis 2008;46(Suppl 3):S251-7. [PubMed: 18284366]

Staib C, Kisling S, Erfle V, Sutter G. Inactivation of the viral interleukin 1beta receptor improves CD8 $+\mathrm{T}$-cell memory responses elicited upon immunization with modified vaccinia virus Ankara. J Gen Virol 2005;86(Pt 7):1997-2006. [PubMed: 15958679]

Staib C, Suezer Y, Kisling S, Kalinke U, Sutter G. Short-term, but not post-exposure, protection against lethal orthopoxvirus challenge after immunization with modified vaccinia virus Ankara. J Gen Virol 2006;87(Pt 10):2917-21. [PubMed: 16963750]

Stittelaar KJ, Neyts J, Naesens L, van Amerongen G, van Lavieren RF, Holy A, De Clercq E, Niesters HG, Fries E, Maas C, Mulder PG, van der Zeijst BA, Osterhaus AD. Antiviral treatment is more effective than smallpox vaccination upon lethal monkeypox virus infection. Nature 2006;439 (7077):745-8. [PubMed: 16341204]

Sutter G, Moss B. Nonreplicating vaccinia vector efficiently expresses recombinant genes. Proc Natl Acad Sci U S A 1992;89(22):10847-51. [PubMed: 1438287]

Sutter G, Moss B. Novel vaccinia vector derived from the host range restricted and highly attenuated MVA strain of vaccinia virus. Dev Biol Stand 1995;84:195-200. [PubMed: 7796954]

Symons JA, Alcami A, Smith GL. Vaccinia virus encodes a soluble type I interferon receptor of novel structure and broad species specificity. Cell 1995;81(4):551-60. [PubMed: 7758109]

Symons JA, Tscharke DC, Price N, Smith GL. A study of the vaccinia virus interferon-gamma receptor and its contribution to virus virulence. J Gen Virol 2002;83(Pt 8):1953-64. [PubMed: 12124459]

Tagaya I, Kitamura T, Sano Y. A new mutant of dermovaccinia virus. Nature 1961;192:381-2. [PubMed: 13918925]

Takahashi-Nishimaki F, Funahashi S, Miki K, Hashizume S, Sugimoto M. Regulation of plaque size and host range by a vaccinia virus gene related to complement system proteins. Virology 1991;181(1): 158-64. [PubMed: 1994573]

Tartaglia J, Cox WI, Pincus S, Paoletti E. Safety and immunogenicity of recombinants based on the genetically-engineered vaccinia strain, NYVAC. Dev Biol Stand 1994;82:125-9. [PubMed: 7958466]

Tartaglia J, Cox WI, Taylor J, Perkus M, Riviere M, Meignier B, Paoletti E. Highly attenuated poxvirus vectors. AIDS Res Hum Retroviruses 1992;8(8):1445-7. [PubMed: 1466978]

Thongcharoen P, Suriyanon V, Paris RM, Khamboonruang C, de Souza MS, Ratto-Kim S, Karnasuta C, Polonis VR, Baglyos L, Habib RE, Gurunathan S, Barnett S, Brown AE, Birx DL, McNeil JG, Kim JH. A phase 1/2 comparative vaccine trial of the safety and immunogenicity of a CRF01_AE (subtype E) candidate vaccine: ALVAC-HIV (vCP1521) prime with oligomeric gp160 (92TH023/ LAI-DID) or bivalent gp120 (CM235/SF2) boost. J Acquir Immune Defic Syndr 2007;46(1):4855. [PubMed: 17909315] 
Thorne CD, Hirshon JM, Himes CD, McDiarmid MA. Emergency medicine tools to manage smallpox (vaccinia) vaccination complications: clinical practice guideline and policies and procedures. Ann Emerg Med 2003;42(5):665-80. [PubMed: 14581920]

Tsang KY, Zhu M, Even J, Gulley J, Arlen P, Schlom J. The infection of human dendritic cells with recombinant avipox vectors expressing a costimulatory molecule transgene (CD80) to enhance the activation of antigen-specific cytolytic T cells. Cancer Res 2001;61(20):7568-76. [PubMed: 11606396]

Tulman ER, Delhon G, Afonso CL, Lu Z, Zsak L, Sandybaev NT, Kerembekova UZ, Zaitsev VL, Kutish GF, Rock DL. Genome of horsepox virus. J Virol 2006;80(18):9244-58. [PubMed: 16940536]

Verardi PH, Jones LA, Aziz FH, Ahmad S, Yilma TD. Vaccinia virus vectors with an inactivated gamma interferon receptor homolog gene (B8R) are attenuated In vivo without a concomitant reduction in immunogenicity. J Virol 2001;75(1):11-8. [PubMed: 11119568]

Vijaysri S, Jentarra G, Heck MC, Mercer AA, McInnes CJ, Jacobs BL. Vaccinia viruses with mutations in the E3L gene as potential replication-competent, attenuated vaccines: intra-nasal vaccination. Vaccine 2008;26(5):664-76. [PubMed: 18096276]

Viner KM, Girgis N, Kwak H, Isaacs SN. B5-deficient vaccinia virus as a vaccine vector for the expression of a foreign antigen in vaccinia immune animals. Virology 2007;361(2):356-63. [PubMed: 17188733]

Webster DP, Dunachie S, Vuola JM, Berthoud T, Keating S, Laidlaw SM, McConkey SJ, Poulton I, Andrews L, Andersen RF, Bejon P, Butcher G, Sinden R, Skinner MA, Gilbert SC, Hill AV. Enhanced $T$ cell-mediated protection against malaria in human challenges by using the recombinant poxviruses FP9 and modified vaccinia virus Ankara. Proc Natl Acad Sci U S A 2005;102(13):483641. [PubMed: 15781866]

Wehrle PF. A reality in our time--certification of the global eradication of smallpox. J Infect Dis 1980;142 (4):636-8. [PubMed: 7003037]

Weyer J, Rupprecht CE, Mans J, Viljoen GJ, Nel LH. Generation and evaluation of a recombinant modified vaccinia virus Ankara vaccine for rabies. Vaccine 2007;25(21):4213-22. [PubMed: 17434244]

Woodland DL. Jump-starting the immune system: prime-boosting comes of age. Trends Immunol 2004;25(2):98-104. [PubMed: 15102369]

Wyatt LS, Carroll MW, Czerny CP, Merchlinsky M, Sisler JR, Moss B. Marker rescue of the host range restriction defects of modified vaccinia virus Ankara. Virology 1998;251(2):334-42. [PubMed: 9837798]

Wyatt LS, Earl PL, Eller LA, Moss B. Highly attenuated smallpox vaccine protects mice with and without immune deficiencies against pathogenic vaccinia virus challenge. Proc Natl Acad Sci U S A 2004;101(13):4590-5. [PubMed: 15070762]

Zhu W, Fang Q, Zhuang K, Wang H, Yu W, Zhou J, Liu L, Tien P, Zhang L, Chen Z. The attenuation of vaccinia Tian Tan strain by the removal of the viral M1L-K2L genes. J Virol Methods 2007;144 (1-2):17-26. [PubMed: 17459491] 
Table 1

Description of vaccinia virus vaccine generations.

\begin{tabular}{|c|c|c|}
\hline \multicolumn{3}{|c|}{ Vaccinia virus vaccines } \\
\hline Generation & Description & Examples \\
\hline 1 st & Jennerian & Dryvax, Lister, Copenhagen \\
\hline 2nd & Tissue culture adapted Jennerian & ACAM2000 \\
\hline $3 \mathrm{rd}$ & Attenuated by passage in an alternative host & MVA, LC16m8, DIs \\
\hline 4 th & Attenuated through genetic engineering & NYVAC, VACVvD4-ZG, VACV $\triangle E 3 L$ \\
\hline
\end{tabular}


Table 2

Adverse events associated with primary vaccinia vaccination

Table illustrates NYCBH strain smallpox vaccine adverse event rates from two studies done in 1968 (Lane et al., 1969; Lane et al., 1970). Current adverse event rates may be expected higher due to increased individuals with 1) immune suppression from cancer, cancer therapy, organ transplantation and other illnesses, such as HIV/AIDS, and 2) eczema or atopic dermatitis. "Common" refers to $25-75 \%$ of vaccines.

\begin{tabular}{|l|l|}
\hline Adverse Event & Number per million vaccinees \\
\hline MILD Reactions & \\
\hline Sore/redness at vaccine site & Common \\
\hline Swollen armpit glands & Common \\
\hline Difficulty sleeping & Common \\
\hline Fever, $>100^{\circ} \mathrm{F}$ & Common \\
\hline Fever, $>102^{\circ} \mathrm{F}$ & 150,000 \\
\hline SERIOUS Reactions & $\sim 1,000$ \\
\hline Erythema multiforme & 164.6 \\
\hline Inadvertent inoculation & $25.4-529$ \\
\hline Generalized vaccinia & $23.4-241$ \\
\hline LIFE-THREATENING Reactions & $14-52$ \\
\hline Eczema vaccinatum & $10.4-38.5$ \\
\hline Progressive vaccinia & $0.9-1.5$ \\
\hline Postvaccinial encephalitis & $2.9-12.3$ \\
\hline Fetal vaccinia & Rare \\
\hline Death & 1.1 \\
\hline & \\
\hline & \\
\hline
\end{tabular}


Table 3

Overview of VACV modifications through genetic engineering.

\begin{tabular}{|c|c|c|c|}
\hline $\begin{array}{l}\text { Deletion of } \\
\text { vaccinia } \\
\text { virus genes }\end{array}$ & N-terminus of E3L & Z-DNA binding domain & At least 1,000 fold less pathogenic than wt virus. ${ }^{1}$ \\
\hline & C-terminus of E3L & dsRNA binding domain & At least 10,000 fold less pathogenic than wt virus. ${ }^{l}$ \\
\hline & E3L & Z-DNA/dsRNA binding protein & Apathogenic in SCID mice model. ${ }^{l}$ \\
\hline & $\mathrm{B} 18 \mathrm{R} / \mathrm{B} 19 \mathrm{R}$ & IFN $\alpha / \beta$ Receptor-like protein & 100 fold less virulent than wt virus in murine intranasal model. ${ }^{2}$ \\
\hline & B8R & IFN $\gamma$ Receptor-like protein & $\begin{array}{l}\text { Deletion of B8R does not affect virulence in normal mice model. }{ }^{3} \text { However, B8R } \\
\text { decreases virulence in nude mice model. }{ }^{4}\end{array}$ \\
\hline & $\mathrm{C} 12 \mathrm{~L}$ & IL-18 binding protein & 10 fold less virulent than wt virus. Induces strong cellular immune response. ${ }^{5}$ \\
\hline & A53R & $\mathrm{TNF} \alpha$ receptor-like protein & 4.6 fold less virulent than wt virus. Induces strong cellular immune response. ${ }^{5}$ \\
\hline & $\mathrm{B} 13 \mathrm{R} / \mathrm{B} 22 \mathrm{R}$ & Serine protease inhibitors & $\begin{array}{l}\text { Replicates as well as wild type virus in vitro. Decreased virulence in normal mice } \\
\text { model. Induces strong humoral response and cell-mediated response. }{ }^{6}\end{array}$ \\
\hline & K1L/C7L & Host Range & $\begin{array}{l}\text { VACV } \Delta \mathrm{C} 7 \mathrm{~L} / \mathrm{K} 1 \mathrm{~L} \text { does not replicate in human cell lines. }{ }^{7} \text { Deletion of C } 7 \mathrm{~L} \text { inhibits } \\
\text { replication in hamster Dede cells. }{ }^{7} \text { Deletion of K1L inhibits replication in RK13 } \\
\text { cells. }\end{array}$ \\
\hline & $\mathrm{J} 2 \mathrm{R}$ & Viral Thymidine Kinase & $\begin{array}{l}\text { Deletion of TK resulted in a } 4 \text { logs attenuated in murine IP or IC model. No } \\
\text { dissemination. }\end{array}$ \\
\hline & B5R & EEV type-I membrane glycoprotein & Deletion of B5R overcomes pre-existing immunity. 10 \\
\hline & D4 & Uracil DNA glycosylation & $\begin{array}{l}\text { No expression of late genes and no DNA replication in non- UDG-complementing } \\
\text { cells. } 11\end{array}$ \\
\hline & A41L & Chemokine binding protein & $\begin{array}{l}\text { Slightly more virulent than wt virus. Enhance VACV immunogenicity and vaccine } \\
\text { efficacy } 12 \text { (Clark et al., 2006) }\end{array}$ \\
\hline & 184R/B15R/B16R & IL-1 $\beta$ receptor & $\begin{array}{l}\text { Deletion of this gene results in avirulent phenotype in MVA. }{ }^{13} \text { This deletion also } \\
\text { enhances } \mathrm{CD} 8^{+} \mathrm{T} \text { cell response } 13,14 \text { after MVA vaccination. }\end{array}$ \\
\hline & $\mathrm{C} 11 \mathrm{R}$ & $\begin{array}{l}\text { VACV epidermal growth factor } \\
\text { (VGF) }\end{array}$ & Deletion of VGF reduces virulent. 15 \\
\hline $\begin{array}{l}\text { Expression } \\
\text { of immune- }\end{array}$ & IL15 & $\begin{array}{l}\text { Establish and maintain peripheral NK } \\
\text { cell populations }\end{array}$ & $\begin{array}{l}\approx 100 \text { fold lower virulence compared to wt in nude mice model. Superior virus- } \\
\text { specific cellular immune response both qualitatively and quantitatively. } 16\end{array}$ \\
\hline & IL-18/IL-12 & $\begin{array}{l}\text { Upon infection, Induce production of } \\
\text { IFN- } \gamma \text { in primed T cells and NK cells }\end{array}$ & $\begin{array}{l}\text { No effect on virus replication in vitro. Decreases VACV replication in murine } \\
\text { model. Co- expression of IL-18 and IL-12 results in a strong immune response, } \\
\text { leading to clearance of VACV infection. } 17\end{array}$ \\
\hline & IL-2 & $\begin{array}{l}\text { Activate specific and non-specific } \\
\text { immune response upon antigenic } \\
\text { stimulation }\end{array}$ & $\begin{array}{l}\text { VACV expressing IL- } 2 \text { is attenuated compared to wt virus. VACV-IL- } 2 \text { was rapidly } \\
\text { clear upon systemic administration in immunodeficient athymic mice. }\end{array}$ \\
\hline & B7-1/CD80 & $\begin{array}{l}\text { Necessary to activate } \mathrm{T} \text { cells by } \\
\text { APCs. }\end{array}$ & $\begin{array}{l}\text { Replication-defective avipox virus expressing CD80 can enhance the efficacy of } \\
\text { human DCs to activate specific human T-cell populations. }{ }^{19}\end{array}$ \\
\hline & IFN- $\gamma$ & $\begin{array}{l}\text { Antiviral, immunoregulatory, and } \\
\text { anti-tumor activity }\end{array}$ & $\begin{array}{l}\text { VACV- } \Delta \mathrm{B} 13 \mathrm{R} / \mathrm{IFN}-\gamma \text { replicates to high titers in tissue culture but is not virulent in } \\
\text { both immnocompromised and immunocmpetent mice. }\end{array}$ \\
\hline \multicolumn{4}{|c|}{$l_{\text {(Vijaysri et al., 2008) }}$} \\
\hline \multicolumn{4}{|c|}{${ }^{2}$ (Symons et al., 1995) } \\
\hline \multicolumn{4}{|c|}{3 (Symons et al., 2002) } \\
\hline \multicolumn{4}{|c|}{${ }^{4}$ (Denes et al., 2006) } \\
\hline \multicolumn{4}{|c|}{${ }^{5}$ (Dai et al., 2008) } \\
\hline
\end{tabular}


${ }^{6}$ (Legrand et al., 2004)

7 (Oguiura et al., 1993)

8 (Meyer et al., 1991)

${ }^{9}$ (Buller et al., 1985)

10 (Viner et al., 2007)

11 (Holzer et al., 1999)

12 (Clark et al., 2006)

13 (Staib et al., 2005)

14 (Cottingham et al., 2008)

${ }^{15}$ (Buller, et al., 1988)

${ }^{16}$ (Perera et al., 2001)

17 (Gherardi et al., 2003)

18 (Flexner et al., 1987)

${ }^{19}$ (Tsang et al., 2001)

20 (Legrand et al., 2005) 


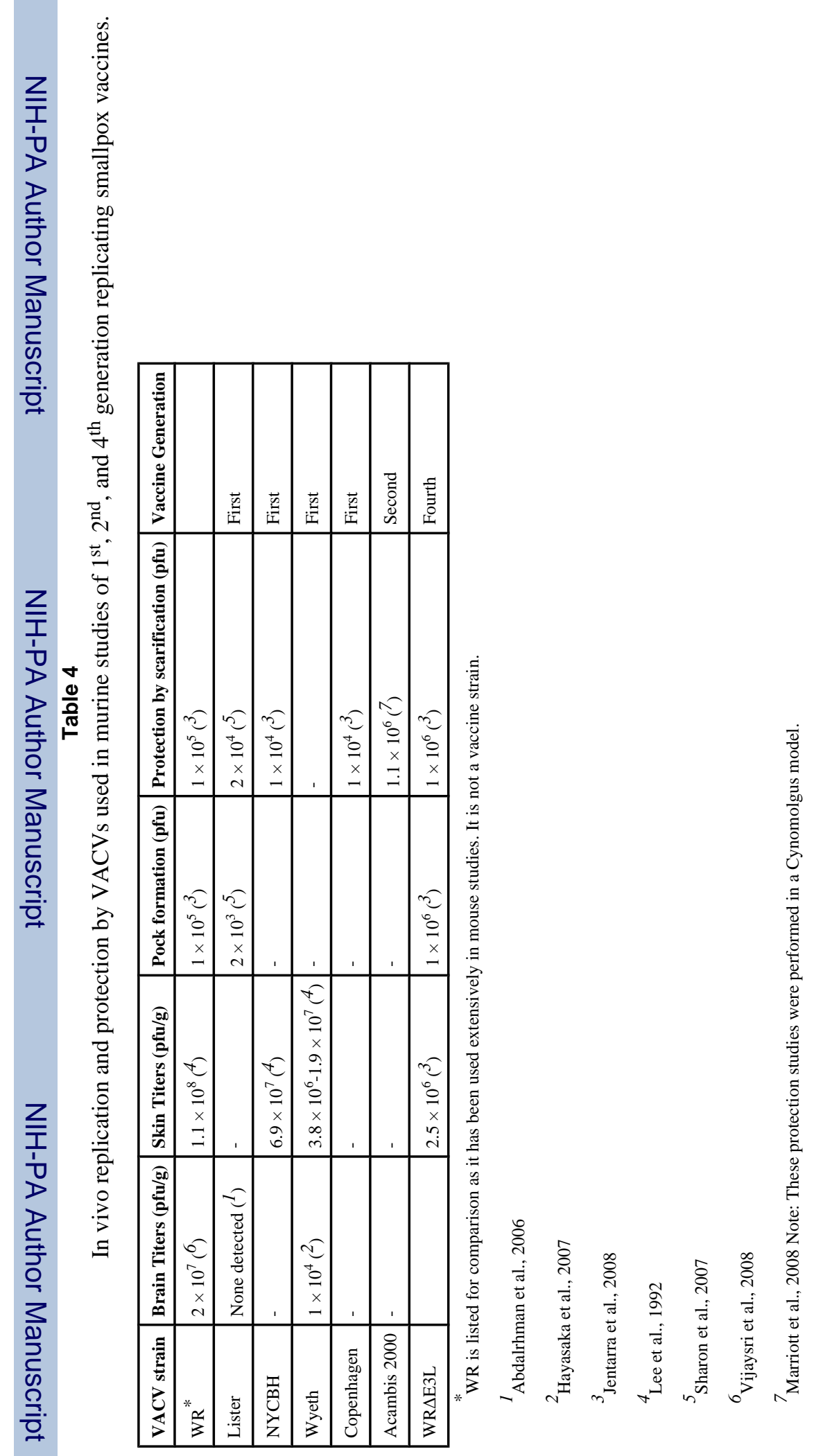

